\title{
New Anticonvulsant Agents
}

\author{
Barbara Malawska*
}

Jagiellonian University, Medical College, Department of Physicochemical Drug Analysis,30-688 Kraków, ul. Medyczna 9, Poland

\begin{abstract}
The search for antiepileptic compounds with more selective activity and lower toxicity continues to be an area of intensive investigation in medicinal chemistry. This review describes new anticonvulsant agents representing various structures for which the precise mechanism of action is still not known. Many of the compounds presented in this review have been tested according to the procedure established by the Antiepileptic Drug Development Program of the Epilepsy Branch of the National Institute of Neurological Disorders and Stroke, National Institute of Health, USA. The newer agents include sulfonamides, amino acids, amides (analogs of $\gamma$-vinyl GABA, $N$-benzylamides, 2,6-dimethylanilides, carboxyamides, hydroxyamides, alkanoamides); heterocyclic agents ((arylalkyl)imidazoles, pyrrolidin-2,5-diones, lactams, semi- thiosemicarbazones, thiadiazoles, quinazolin-4(3H)-ones, 2,5-disubstituted 1,2,4-thadiazoles, xanthones, derivatives of isatin) and enaminones. These new structural classes of compounds can prove useful for the design of future targets and development of new drugs.
\end{abstract}

Key Words: Anticonvulsant agents, Structure - Activity - Relationships,

\section{INTRODUCTION}

Epilepsy is a common neurological condition, affecting 0.5 to $1 \%$ of the population worldwide (45-100 million people) [1]. Conventional antiepileptic drugs (AEDs) phenobarbital, primidone, phenytoin, carbamazepine, ethosuximide and benzodiazepine, are widely used but exhibit an unfavorable site effect profile and failure to adequately control seizures. In the recent years several new drugs (oxcarbazepine, lamotrigine, topiramate, gabapentin, zonisamide, tiagabine, fosphenytoin, vigabatrin and felbamate) have been added to the list of therapeutic agents against epilepsy. However, there is a significant group of patients (up to 30\%) who are resistant to the available antiepileptic drugs. The long-established AEDs control seizures in $50 \%$ of patients developing partial seizures and in $60-70 \%$ of those developing generalized seizures [2-6]. Hence, there is an urgent need to develop new AEDs [7].

The search for antiepileptic compounds with a more selective activity and lower toxicity continues to be an area of investigation in medicinal chemistry. A rational drug design process of a new anticonvulsant could be achieved in several ways $[8,9]$. The first strategy is the identification of new targets through better understanding of molecular mechanisms of epilepsy. Another way is to modify already existing drugs and formulations. AEDs belong to many different chemical classes of compounds, including: hydantoines, iminostilbenes, barbiturates, benzodiazepines, valproate, imides, oxazolidine-2,3-diones, sulfonamides and miscellaneous agents [10]. The efficacy of AEDs is due to the main activities which include interaction with ion channels or neurotransmitter systems [11-17]. Currently

\footnotetext{
*Address correspondence to this author at Jagiellonian University, Medical College, Department of Physicochemical Drug Analysis, 30-688 Kraków, ul. Medyczna 9, Poland; Tel: (48 12) 6570560; Fax: (48 12) 6570262; E-mail: mfmalaws@cyf-kr.edu.pl
}

available AEDs can be broadly classified into four categories: (1) those whose main action relates to the inhibition of sustained repetitive firing, through blockage of voltage-dependent sodium channels and consequent inhibition of the release of excitatory neurotransmitters (phenytoin, carbamazepine, oxcarbazepine); (2) those which enhance GABA-ergic transmission (benzodiazepines, barbiturates, vigabatrin, tiagabine); (3) those stabilizing thalamic neurons through inhibition of T-type calcium channels (ethosuximide) and (4) those possessing a combination of the above actions, often coupled with additional mechanisms (valproic acid, gabapentin, lamotrigine, topiramate, zonisamide, felbamate). However, this classification has limited value because the majority of AEDs possess more than one mechanism of action, which may account for their efficacy, and it is also the fact that some of the clinically used drugs have not been linked with a specific site the brain, and the exact mechanisms of many AEDs remain unknown [18,19].

The new AEDs and anticonvulsant agents have been reviewed during last few years [20-24]. The chemical diversity and various mechanisms of action of anticonvulsants make it difficult to find a common way of identifying new drugs. Novel anticonvulsant agents are discovered through conventional screening and/or structure modification rather than a mechanism-driven design. Therefore, drug identification is usually conducted via in vivo screening tests, on the basis of seizure type rather than etiology.

This review presents new anticonvulsant agents representing various structures for which the precise mechanism of action is still not known. The newer agents include heterocyclic compounds, sulfonamides, amino acids, amides, enaminones and others. These new structural classes of compounds can be useful for the design of future targets and development of new drugs.

(C) 2005 Bentham Science Publishers Ltd. 


\section{THE ANTICONVULSANT SCREENING PROJECT (ASP)}

Many of the compounds presented in this review have been tested according to the procedure established by the Antiepileptic Drug Development (ADD) Program [25, 26]. Since 1975, the Epilepsy Branch of the National Institute of Neurological Disorders and Stroke, National Institute of Health, through its Antiepileptic Drug Development (ADD) Program, has collaborated with the pharmaceutical industry in developing new therapeutic agents for the treatment of seizure disorders. In 1993 felbamate, the first new drug in nearly two decades, was approved for sale in the United States. Felbamate's development was a collaborative effort of both a pharmaceutical sponsor and the ADD Program. Two other drugs, topiramate and remacemide have been identified in the Branch's preclinical evaluation and are now in late clinical development. Several other drugs, losigamone, retigabina, soretolide and rufinamide (Fig. 1) are now in early clinical development [27-29]. The ADD Program boasts of both preclinical and clinical trial components. The preclinical component consists of drug discovery and toxicology elements. The Anticonvulsant Screening Project uses for its initial screening procedure two major convulsant tests: maximal electroshock (MES) and subcutaneous pentylenetetrazole (scPTZ) as well as a toxicity screen (rotorod in mice, positional sense and gait in rats). The MES is a model for generalized tonic-clonic seizures. The behavioral and electrographic seizures generated in this model are consistent with the human disorder [30]. This model identifies those compounds which prevent the spread of seizures. The scPTZ seizure test is a model which primarily identifies compounds that raise seizure threshold. The behavioral seizure produced is not typical of absence epilepsy but clonic in nature. Like other rodent models of<smiles>COC1=CC(=O)OC1C(O)c1ccccc1Cl</smiles>

losigamone<smiles>NC(=O)c1cn(Cc2c(F)cccc2F)nn1</smiles>

rufinamide<smiles>CCOC(=O)Nc1ccc(NCc2ccc(F)cc2)cc1N</smiles>

retigabine

s ore tolide<smiles>Cc1cc(NC(=O)c2c(C)cccc2C)no1</smiles>

cromakalim



absence seizures, PTZ-induced seizures are potentiated by $\gamma$ aminobutyric acid (GABA) agonist. With some minor exceptions, the pharmacological profile of the scPTZ seizure model is consistent with the human condition [30, 31]. All clinically active anticonvulsants have been found to be protective in at least one of these two tests.

Compounds that possess significant anticonvulsant activity in rats and in mice and do not exhibit substantial neurotoxicity or lethality are considered for the ADD Program's multiphase evaluation to establish a compound's pharmacodynamic/pharmacokinetic profile. During the past five years, over 4000 compounds have been evaluated by the ADD Program. Selected results of these evaluations have been published and are presented in this review.

\section{NEW ANTICONVULSANT AGENTS: STRUCTURE - ACTIVITY - RELATIONSHIPS}

\section{Heterocyclic Analogs of Carabersat}

Carabersat (SB-204269) was originally designed by modifying the structure of cromakalim (Fig. 2). This later drug represents a class of antihypertensive agents which act via the relaxation of vascular smooth muscle caused by the opening of ATP-sensitive potassium channels. The potassium channel activators which more readily penetrate the central nervous system (CNS) may have therapeutic potential in the treatment of epilepsy [11]. Replacement of the 2-pyrrolidinone group of cromakalim by the fluorobenzoylamino group has introduced anticonvulsant activity [32]. Carabersat, the benzopyran derivative, is a chemically novel AED with a novel mechanism of action and a stereospecific CNS binding site. It has potent oral anticonvulsant properties in a range of rat seizure models, with potency and efficacy equivalent to or better than carbamazepine and lamotrigine. Carabersat is currently being proposed for the treatment of epilepsy and migraine prophylaxis $[33,34]$. Subsequent exploration of structureactivity-relationships, using high-throughput screening of the novel SB-204269 binding site led to the identification of anticonvulsant active series of the isomeric tetrahydroisoquinolinyl (THIQ) benzamides 5-, 7- and 8-substituted $[35,36]$. Compound SB-270664, the 7-substituted THIQ was

Fig. (2). The structure of cromakalim and carabersat.

Fig. (1). Chemical structures of new anticonvulsant drugs. 
reported as a promising key lead compound with high affinity at the $\left[{ }^{3} \mathrm{H}\right]-\mathrm{SB}-204269$ binding site $\left(\mathrm{p} K_{\mathrm{i}} 8.9\right)$, but was later found to have poor pharmacokinetic properties. The major routes of metabolism of this compound were hydroxylation of the THIQ benzo ring, $N$-demethylation and aromatization to the isoquinolinium species. Starting from a series of 7-linked THIQ derivatives, a new series of 8,8dimethylnaphthyridine compounds has been identified (Fig. 3). In this series a gem dimethyl group is incorporated to prevent aromatization, and replacement of the THIQ benzo ring with pirydyl represents an attempt to reduce hydroxylation. In this new series, compound $\mathbf{1}$ was identified as new potential agent displaying excellent anticonvulsant activity and an encouraging pharmacokinetic profile in vivo. Compound $\mathbf{1}$ has high affinity at the $\left[{ }^{3} \mathrm{H}\right]-\mathrm{SB}-204269$ binding site $\left(\mathrm{p} K_{\mathrm{i}}\right.$ 8.7), suggesting a novel mechanism of action, comparable with carabersat. In vivo, the rat maximal electroshock threshold (MEST) test at $2 \mathrm{mg} \mathrm{kg}^{-1}$ p.o. compound 1 showed a good level of anticonvulsant activity. In the rat supraMES model, analysis by 'ALLFITrd-quo compound 1 produced an $\mathrm{ED}_{50}$ value of $3.9 \mathrm{mg} \mathrm{kg}^{-1}$. This figure is comparable with that obtained with carabersat in the same model under identical conditions ( $\mathrm{ED}_{50}$ of $\left.6.3 \mathrm{mg} \mathrm{kg}^{-1}\right)$. Compound 1 has excellent aqueous solubility $\left(>1 \mathrm{mg} \mathrm{mL}^{-1}\right)$ and has been shown to have an encouraging pharmacokinetic profile and good in vivo activity in preclinical anticonvulsant models in rats [37].

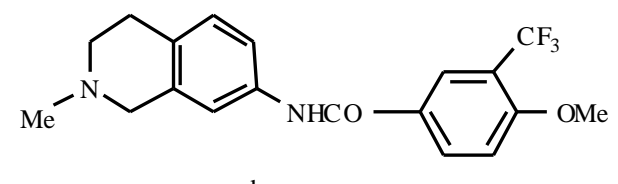

compound

SB-270664

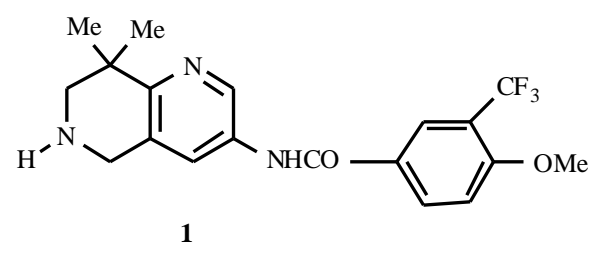

Fig. (3). Heterocyclic analog of carabersat.

\section{Sulfonamides}

Acetazolamide $\{N$-(5-aminosulfonyl)-1,3,4-thiadiazol-2yl acetamide $\}$ and methazolamide are old members of this class, which have shown anticonvulsant activity (Fig. 4). These drugs are bifunctional 5-membered heterocycles, comprised of a sulfonamide and an amide as well as a 1,3,4thiazole nucleus, constituting potent carbonic anhydrase (CA) inhibitors. Several new sulfonamide CA inhibitors such as topiramate and zonisamide have been and are still used as antiepileptic drugs (Fig. 4). The anticonvulsant effects of these or related sulfonamides are probably due to $\mathrm{CO}_{2}$ retention secondary to the inhibition of red cell and brain enzymes, but other mechanisms of action, such as blockade of sodium channels and kainite/AMPA receptors, as well as enhancement of GABA-ergic transmission, have also been<smiles>CC(=O)Nc1nnc(S(N)(=O)=O)s1</smiles>

acetazolamide<smiles>CC1(C)CO[C@]2(COS(N)(=O)=O)[C@H](O[C@H]3OC(C)(C)O[C@H]32)O1</smiles>

topiramate<smiles>CC(=O)/N=c1\sc(S(N)(=O)=O)nn1C</smiles>

methazol amide
Fig. (4). Sulfonamide antiepileptic drugs.

hypothesized/proven for some of these drugs. Acetazolamide and methazolamide are still clinically used nowadays in some forms of epilepsy, but they are considered to belong to a minor class of antiepileptic agents. The recently developed drug topiramate is a very effective antiepileptic, and it also acts as a strong CA inhibitor with a potency similar to that of acetazolamide against the physiologically important isoenzyme CA II [38-40]. Acetazolamide, topiramate and zonisamide possess a sulfamate moiety, which is essential for their anhydrase inhibition. Several new carbonic anhydrase inhibitors derivatives of sulfonamide have been developed by Scozzafava, Supuran and coworkers [41-46]. A series of aromatic/heteroaromatic sulfonamides incorporating valproyl and other lipophylic moieties has been found to possess potent $\mathrm{CA}$ inhibitory properties as well as anticonvulsant in vivo effects. The hybride compound, valproyl derivative of acetazolamide (5-valproylamido-1,3,4thadiazole-2-sulfonamide, 2) was one of the best hCA I and hCA II (human cloned isoenzymes) inhibitors in the series and it exhibited very strong anticonvulsant properties in the MES test in mice [45]. Inhibition data of carbonic anhydrase $K_{\mathrm{i}}(\mathrm{nM}) \mathrm{hCA}$ I and hCA II are as follows: for topiramate 250 , 5; for compound 256,6 . Both drugs efficiently protected mice against seizures induced by electroshock at a dosage of $30 \mathrm{mg} \mathrm{kg}^{-1}$; the protection rate was $75-100 \%$ at $0.5 \mathrm{~h}$ and $25-100 \%$ at $3 \mathrm{~h}$ after drug administration. Investigation at a decreased dosage of $10 \mathrm{mg} \mathrm{kg}^{-1}$ of compound 2 showed a rate of protection in the range of $25-44 \%$ at $0.5 \mathrm{~h}$ and $87-$ $100 \%$ at $3 \mathrm{~h}$ after administration. Several other 1,3,4thiadiazole-sulfonamide derivatives possessing potent CA inhibitory properties and substituted with various alkyl/ arylcarboxamido/sulfonamide/ureido moieties in the 5position have been investigated for their anticonvulsant effects in the same animal model. It was observed that some lipophilic derivatives, such as 5-benzoylamido-, 5toluenesulfonylamido-, 5-adamantylcarboxamido-, and 5pivaloylamido1,3,4-thiadiazole-2-sulfonamide, show promising in vivo anticonvulsant properties and that these compounds may be considered as interesting leads for 
developing anticonvulsant or selective cerebrovasodilator drugs [46]. A new series of sulfonamides incorporating adamantyl moieties attached to the scaffolds of aromatic/heteroaromatic sulfonamides have shown good inhibitory potency against two human CA isozymes, compound 3 and 4 (Fig. 5), inhibition data of carbonic anhydrase $K_{\mathrm{i}}(\mathrm{nM}) \mathrm{hCA}$ I and hCA II are as follows: for compound 3 850, 10; for compound 4 77-, 12. The anticonvulsant activity of these two CA inhibitors against MES tests in mice revealed that after i.p. injection $(30 \mathrm{mg}$ $\mathrm{kg}^{-1}$ ), compounds $\mathbf{3}$ and $\mathbf{4}$ exhibit good protection against electrically-induced convulsions $(>90 \%)$. Their $\mathrm{ED}_{50}$ values were 3.5 and $2.6 \mathrm{mg} \mathrm{kg}^{-1}$, respectively.

<smiles>NS(=O)(=O)c1nnc(NC(=O)C23CC4CC(CC(C4)C2)C3)s1</smiles>

3

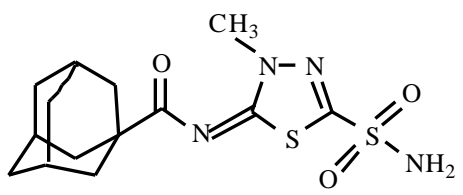

4

Fig. (5). Anticonvulsant sulfonamides carbonic anhydrase inhibitors.

\section{Derivatives of Amino Acids}

Amino acids that are functionalized at both the $N$ - and $C$ terminal are proven potent anticonvulsant agents [47-72]. In the recent years, Kohn and coworkers have reported on the anticonvulsant activity of a series of functionalized amino acids [47-61] (FAA) 5 (Fig. 6). A structure activity relationships study of over 250 compounds has yielded 12 compounds with anticonvulsant activity in rodents that is equal to or greater than phenytoin according to the MESseizure test. $N$-Benzyl-2-acetamidopropionamide 9 was the parent compound in this series [55]. These investigations have enabled the selection of $(R)$ - $N$-benzyl-2-acetamido-3methoxy-propionamide $\mathbf{1 0}$ as the lead compound (Table $\mathbf{1}$ ). Compound $\mathbf{1 0}$ has now entered phase II clinical trials for the treatment of epilepsy and neuropatic pain. Extensive SAR study of FAA 5 revealed that the $N$-terminus is an important FAA structural unit. In the initial design of FAA, the $N$ terminal amine was protected as an amide to provide compounds with increased lipophilicity. Subsequent studies demonstrated the importance of the acetamido unit $\left(R_{1}\right.$ $\left.=\mathrm{C}(\mathrm{O}) \mathrm{CH}_{3}\right)$ for potent anticonvulsant activity and showed that either a decrease (i.e., $\mathrm{R}_{1}=\mathrm{C}(\mathrm{O}) \mathrm{H}$ ) or increases (i.e., $\mathrm{R}_{1}$ $\left.\left.\left.=\mathrm{C}(\mathrm{O}) \mathrm{CH}_{2} \mathrm{CH}_{3}, \mathrm{C}(\mathrm{O}) \mathrm{C}(\mathrm{H}) \mathrm{CH}_{3}\right)_{2}, \mathrm{C}(\mathrm{O}) \mathrm{CCH}_{3}\right)_{3}\right)$ in the size

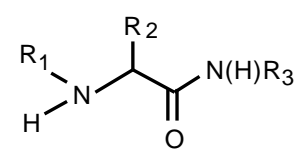

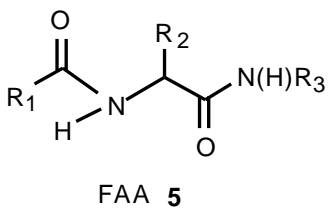

functionalized amino acids<smiles>[R7]NC([R7])C([R8])=O</smiles>

FAK 7

functionalized amido ketones<smiles>[R]NC(=O)N([R2])[2H]</smiles>

semicarbazides 6

aza analogues of funcionalized amino acids<smiles>[R2]C(C(=O)NCc1ccccc1)N([R])[R]</smiles>

AAA 8

amino acid amides
Fig. (6). The schematic structure of anticonvulsant derivatives of amino acids.

of this moiety led to reduced activity. Furthermore, when the acetamido $\left(\mathrm{CH}_{3} \mathrm{C}(\mathrm{O}) \mathrm{NH}\right)$ unit in $\mathbf{5}$ was replaced with methyl, methoxy, hydroxyl, acetoxy, or halogen, the obtained compounds exhibited diminished anticonvulsant activity. Structural modifications also included replacing the $\mathrm{C}(2)$ unit with the corresponding $\mathrm{N}(2)$ group giving the structurallyrelated semicarbazide derivatives 6 [57]. Evaluation of aza analogues $\mathbf{6}$ of functionalized amino acids in both mice (i.p.) and rats (p.o.) showed that the compounds exhibited significant anticonvulsant activities but in most cases at levels lower than their amino acid counterparts. Comparison of a selected series of semicarbazides $\mathbf{6}$ with their FAA counterparts 5 showed that replacing the tetrahedral $\mathrm{C}(2)$ carbon in $\mathbf{5}$ with a trivalent $\mathrm{N}$ led to a reduction in pharmacological activity in most cases upon administration to mice (i.p.). It was found that oral administration of the $\mathrm{N}(2)$-substituted semicarbazides to rats led to improved anticonvulsant activities. Of the investigated compounds, 1acetyl-4-benzyl-2-(thiazol-2-yl)-semicarbazide $\mathbf{1 1}$ displayed moderate-excellent activity in mice (MES i.p. $\mathrm{ED}_{50}=22 \mathrm{mg}$ $\mathrm{kg}^{-1}, \mathrm{PI}=5.4$ ) and excellent activity in rats (MES p.o. $\mathrm{ED}_{50}=$ $6.2 \mathrm{mg} \mathrm{kg} \mathrm{kg}^{-1}$, Tox $\mathrm{TD}_{50}>250$ ) which exceeded that of phenytoin (Table 1).

Conformationally restricted analogues of anticonvulsant functionalized amino acids have also been investigated [56]. Four peptidomimetic compounds of parent FAA 9 such as 1,5-disubstituted tetrazole 12, 3-substitued 1-benzylpyrrolidin-2-one 13, proline 14, and (thio)hydantoins 15, 16 as well as peptidomimetic FAA derivatives have been evaluated (Fig. 7). No improvement in pharmacological activity was observed upon conformational constraint, however new important information on the SAR of FAAs was obtained. It was shown that FAAs(1)-alkylation did not reduce anticonvulsant activity while $\mathrm{N}(3)$-alkylation led to appreciable activity loss. These studies also revealed that derivatives of hydantoin $\mathbf{1 5}$ and thiohydantoin 16, upon p.o. 
Table 1. Selected Pharmacological Data for Amino Acids Derivatives and their Reference Compounds [56].

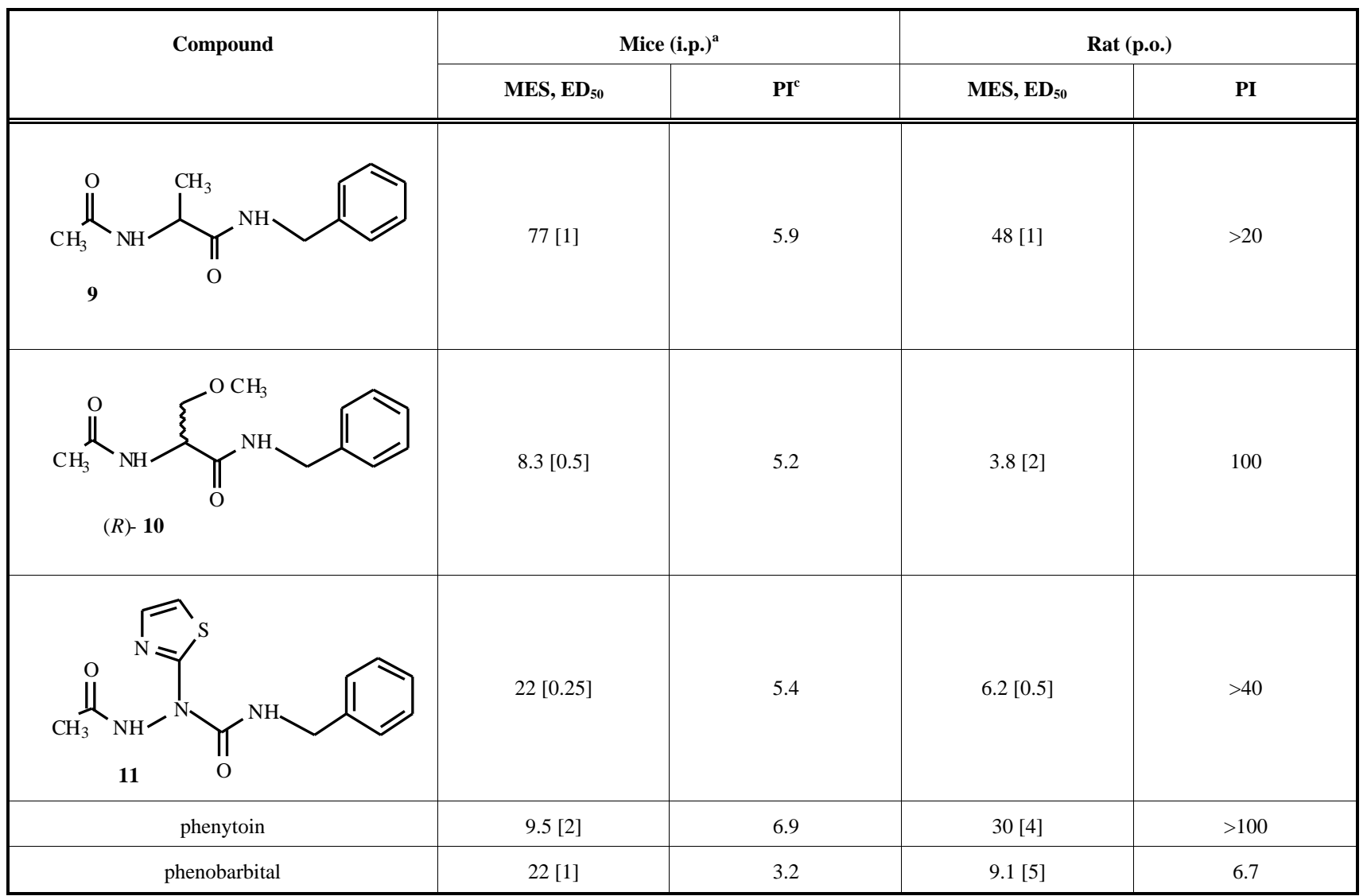

${ }^{a} \mathrm{ED}_{50}$ and $\mathrm{TD}_{50}$ values are in $\mathrm{mg} \mathrm{kg}{ }^{-1}$. Numbers in parentheses are $95 \%$ confidence intervals. The dose effect data was obtained at the 'time of peak effect' (indicated in $\mathrm{h}$ in the square brackets).<smiles>CC(=O)NC(C)c1nnnn1Cc1ccccc1</smiles>

12<smiles>CC(=O)NC1CCN(Cc2ccccc2)C1=O</smiles>

13<smiles>CC(=O)N1CCCC1C(=O)NCc1ccccc1</smiles>

14<smiles>CC(=O)N1C(=O)N(Cc2ccccc2)C(=O)C1C</smiles>

15<smiles>CC(=O)N1C(=S)N(Cc2ccccc2)C(=O)C1C</smiles>

16

Fig. (7). Conformationally restricted analogs of anticonvulsant functionalized amino acids (FAAs).

administration, respectively, displayed activity comparable with phenytoin in the MES-seizure test in rats. The $\mathrm{ED}_{50}$ value for compound $\mathbf{1 5}$ in rats (p.o.) was $27 \mathrm{mg} \mathrm{kg}^{-1}$, while compound 16 protected half of the rats tested at $40 \mathrm{mg}$. After i.p. administration of compound $\mathbf{1 6}$ in rats, the $\mathrm{ED}_{50}$ value was impressive, at $12 \mathrm{mg} \mathrm{kg}^{-1}$ in the MES-seizure test. Both compounds possessed moderate-to-good activity in the scPTZ-seizure test in mice. The most active compound was $16\left(\mathrm{ED}_{50}=46 \mathrm{mg} \mathrm{kg}^{-1}, \mathrm{PI}=2.5\right)$. These findings contrasted with the lack of scPTZ-activity exhibited by FAA analogues 9, 10 and phenytoin. It was concluded, that FAAs and their monosubstituted hydantoin analogues exhibited different anticonvulsant profiles. The activities of compounds 9, 10 and $\mathbf{1 5}$ in the volatage-sensitive $\mathrm{Na}^{+}$channel test using patch-clamp electrophysiology techniques were tested. Hydantoin 15 exhibited significant voltage-dependant blockade of $\mathrm{Na}^{+}$channels $(35 \%$ blockage at $-60 \mathrm{mV}$ ), while the two FAAs (9 and $(R)-10$ ) had no significant effect on peak current at $100 \mu \mathrm{M}$. Two prototypical antiepileptic $\mathrm{Na}^{+}$ channel blockers, phenytoin and lamotrigine, provided 48 and $53 \%$ blockage at $-60 \mathrm{mV}$, respectively. These findings indicate that $\mathbf{1 5}$ expresses its anticonvulsant activity in part by acting on the $\mathrm{Na}^{+}$channel. The divergent SAR and the different electrophysiological findings for (thio)hydantoins and FAAs provided evidence that these two classes of compounds function by different mechanisms.

Replacing the $N$-terminal amide group in FAA with phenylethyl, styryl, and phenylethynyl units provided a series of functionalized amido ketones (FAK) 7 [60] (Fig. 8). It was determined that FAK exhibit excellent anticonvulsant activities that approach those observed for their FAA 


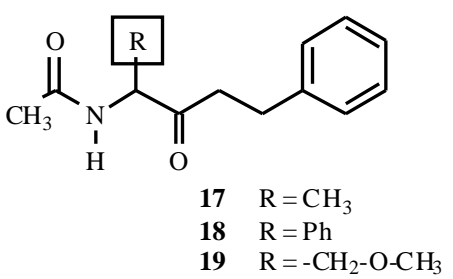

Fig. (8). Funcionalized amido ketones (FAK).

counterparts in rats. The saturated FAK 17-19 displayed a comparable activity pattern when administered to rats (p.o.) The $\mathrm{ED}_{50}$ values for 17, 18, and 19 were 47,23 , and $18 \mathrm{mg}$ $\mathrm{kg}^{-1}$ respectively. The $\mathrm{ED}_{50}$ values for $\mathbf{1 8}$ and 19 compared favorably with phenytoin $\left(\mathrm{ED}_{50}=30 \mathrm{mg} \mathrm{kg}^{-1}\right)$ and phenobarbital $\left(\mathrm{ED}_{50}=9.1 \mathrm{mg} \mathrm{kg}{ }^{-1}\right)$, and both 18 and 19 exhibited PI values that exceeded 14. The favorable activities for FAK have been attributed to the incorporation of key $\mathrm{R}$ structural units within the FAK backbone and conformation of the terminal ketone unit.

Conversion of the acetamido unit in $\mathbf{5}$ to an amino moiety provided amino acid amides (AAA, 8) that are likely to have increased water solubility compared with their FAA 5 counterparts [61]. It was demonstrated that AAA 8 are potent anticonvulsants, and that the terminal amino group is prone to metabolic change. Among the investigated compounds, 20 displayed in MES test (i.p. mice) a protection level of $\mathrm{ED}_{50}=$ $36 \mathrm{mg} \mathrm{kg}^{-1}, \mathrm{PI}=2.0$, (p.o. rats) $\mathrm{ED}_{50}=7.1 \mathrm{mg} \mathrm{kg}^{-1}, \mathrm{PI}=33$. The AAA anticonvulsant activity was neither strongly influenced by the $\mathrm{C}(2)$ substituent nor by the degree of terminal amine substitution (Fig. 9). The mechanism of action of FAA remains elusive.<smiles>CN(C)C(C(=O)NCc1ccccc1)c1ccccc1</smiles>

Fig. (9). Structure of $N$-substituted amino acid $N$-benzylamide (AAA).

Some amino acid derivatives have also been studied by Paruszewski and coworkers [62-67]. Amides of $N$ substituted natural and anatural amino acids containing benzylamide, 4-fluorobenzylamide, 4-methoxybenzylamide, 2-furfurylamide, phenylethylamide, 3-pirydylmethylamide, buthylamide, isobuthylamide, usoamylamide moiety as well as esters have been synthesized and evaluated according to the procedure of the ASP of NINDS. Among the tested compounds, benzylamide derivatives of $\beta$-Ala $(\mathbf{2 1}, 22)$, Ac$D$-Pro-BZA (23) and $(R, S)$-Me-Tzl-BZA (24) were the most active. They exhibited (in MES test after i.p. administration in mice), a significant protective index (PI) of 3.2 for 21 $\left(\mathrm{ED}_{50}=31.17 \mathrm{mg} \mathrm{kg}^{-1}\right)$ and 4.3 for $22\left(\mathrm{ED}_{50}=53.47 \mathrm{mg} \mathrm{kg}^{-}\right.$ $\left.{ }^{1}\right)$ and, following oral administration in rats, PI> 18 with $\mathrm{ED}_{50}$ $=27.33 \mathrm{mg} \mathrm{kg}^{-1}$ for 21 and $>14$ with $\mathrm{ED}_{50}=34.05 \mathrm{mg} \mathrm{kg}^{-1}$ for 22. Benzylamide 23 protected against MES and scPTZ seizure in mice after i.p. administration with $\mathrm{ED}_{50}=64.41$ $\mathrm{mg} \mathrm{kg}{ }^{-1}(\mathrm{MES})$ and $\mathrm{ED}_{50}=183.78 \mathrm{mg} \mathrm{kg}^{-1}$ with $\mathrm{PI}=4.5$ (scPTZ). The benzylamide of $N$-methyl-thiazolidine-4carboxylic acid 24 was active in MES seizure after i.p. administration in mice with $\mathrm{ED}_{50}=29.05 \mathrm{mg} \mathrm{kg}^{-1}$ and $\mathrm{PI}=$ 3.77. Recent studies have demonstrated that some picoline and nicotinic acid benzylamides substituted on the phenyl ring also possess anticonvulsant properties [65-67]. Of these, the most active was the picolinic acid fluorobenzylamide (Pic-FBZA 25). $\mathrm{ED}_{50}$ of the most effective amide 25 was $14.7 \mathrm{mg} \mathrm{kg}^{-1}$ (MES), >50 mg kg-1 (scPTZ) and PI $<3.4$ against MES (rats, i.p.) [66].

SAR studies of alanine derivatives suggested that the structure of this amino acid, especially of fragment $\mathrm{N}-\mathrm{C}^{\alpha}-\mathrm{C}^{\prime}$, is responsible for its action [62]. It was also found that with an $\alpha$-amino acid structure, and $N$-acyl- or $N$-alkyl group, a small substituent at $\mathrm{C}-\alpha$ or an aromatic amide substituent appear to be the most useful for anticonvulsant activity [64]. The importance of the benzylamide group of anticonvulsant active amino acids was confirmed both by Kohn's and Paruszewski's research groups.

Derivatives of arylidene imidazoline-4-one amino acids were investigated by Kieć-Kononowicz and KarolakWojciechowska [68-71]. Several series of arylidene(aryl)imidazolidyno-4-one derivatives incorporating glycine, modified glycine or $\alpha$-alanine and modified $\alpha$-alanine were studied as a new ligand for the glycine-NMDA binding site (iGluRs) as well as anticonvulsant agents. Selected amino acid derivatives (26-29) presented in Fig. 10 displayed anticonvulsant activity in MES seizure tests at a dosage of $100 \mathrm{mg} \mathrm{kg}^{-1}$ or less.

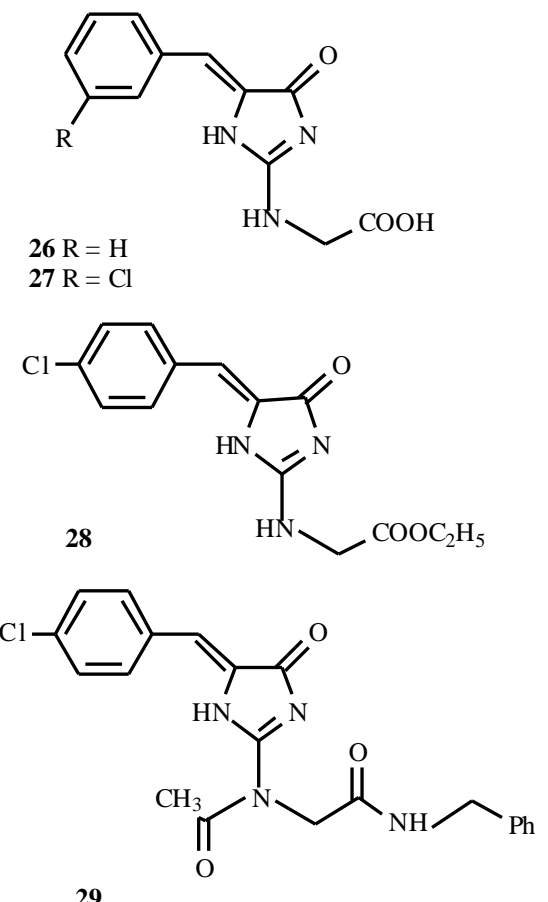

Fig. (10). Arylidene-imidazoline-4-one aminoacids. 


\section{AMIDES}

\section{Analogs of $\gamma$-vinyl GABA}

Vigabatrin ( $\gamma$-vinyl GABA) is being proposed as an anticonvulsant agent with a mechanism reportedly based on an inhibitor of GABA aminotransferase [17]. Lee and coworkers have developed several analogs of vigabatrin as potential dual acting prodrugs which were covalently coupled with an amide bond of vigabatrin and GABA mimetic substances such as GABA, $\gamma$-vinyl GABA, valproic acid, isonipecotic acid, nipecotic acid and 2-pyrrolidinone [73, 74]. Most of these compounds have shown moderate anticonvulsive activities. Among them, compounds $\mathbf{3 0}$ and 31 displayed the most potent anticonvulsive activity and a broader spectrum when compared to vigabatrin (Fig. 11). Compounds 30 and 31 were active against $\mathrm{MES}\left(\mathrm{ED}_{50}=\right.$ 0.64, 0.76), scPTZ $\left(\mathrm{ED}_{50}=0.58,0.40\right), \mathrm{BIC}\left(\mathrm{ED}_{50}=0.47\right.$, $0.34)$ and PCR $\left(\mathrm{ED}_{50}=0.47,0.49 \mathrm{mmol} \mathrm{kg}{ }^{-1}\right)$ seizure tests respectively.<smiles>C=CC(N)CCC(=O)NCCCC(=O)OC</smiles>

30<smiles>C=CC(CCC(C)=O)NC(=O)CCCN</smiles>

31

Fig. (11). Analogs of $\gamma$-vinyl GABA.

\section{$N$-Benzylamides of $\gamma$-hydroxybutyric Acid}

Derivatives of $\alpha$-substituted $\gamma$-amino-, $\gamma$-phthalimido-, $\gamma$ acetoxy- and $\gamma$-hydroxy butyric acid, such as acids, esters and amides, have been investigated as new potent anticonvulsants [75-84]. It has been shown that $\alpha$-substitutes $N$ benzylamides of $\gamma$-hydroxybutyric acid (GHB) are the most potent compounds in this group, possessing anticonvulsant activities in MES (i.p. in mice) screens. The most potent anticonvulsants were $\alpha$-(benzylamino)- $\gamma$-hydroxybutyric acid $N$-benzylamide 32 and $N$-(2-chlorobenzylamide) 33 (Fig. 12); their $\mathrm{ED}_{50}$ being respectively 63.0 and $54.0 \mathrm{mg}$ $\mathrm{kg}^{-1}$. In the MES screen, these compounds were less active than the commonly used anticonvulsants carbamazepine and phenytoin, but possessed higher activity than sodium valproate [79]. Biochemical tests have indicated that the active amides act as allosteric modulators of the $\gamma$-aminobutyric acid, $\mathrm{GABA}_{\mathrm{A}}$ complex, and have an affinity to voltage-sensitive calcium channel receptors. $N$-(4-methylbenzyl)amide of $\alpha$-(4-phenylpiperazin-1-yl)- $\gamma$ hydroxybutyric acid 34 displayed the binding of $\left[{ }^{35} \mathrm{~S}\right] \mathrm{TBPS}$ ( $\left[{ }^{35} \mathrm{~S}\right]$ tert-buthylbicyclophosphorothionate) to the chloride channel of the $\mathrm{GABA}_{\mathrm{A}}$ receptor complex $\left(\mathrm{IC}_{50}=95 \mu \mathrm{M}\right)$ [80]. This may be the possible mechanism mediating the anticonvulsant effect of these compounds. The results of pharmacological in vivo experiments with the $\gamma$ hydroxybutyric acid amide analogues $\mathbf{3 2}$ and $\mathbf{3 3}$ have shown that the compounds possess variable influence on the CNS in mice [81].



Fig. (12). $\alpha$-Substituted $N$-benzylamides of $\gamma$-hydroxybutyric acid.

SAR studies have enabled the definition of structural elements responsible for the anticonvulsant activity of these several series of compounds [83, 84]. These features are as follows: the presence of the $N$-benzylamide fragment, a hydrophobic unit (aryl ring) as a distal binding site and a group which could act as an $\mathrm{H}$-bond donor. It was also concluded that a hydroxyl group was necessary for MES activity, and more lipophylic compounds showed better anticonvulsant properties [82].

\section{2,6-dimethylanilides, Carboxamides}

The activity of several 2-piperidinecarboxyamides in the MES test in mice has been reported $[85,86]$. Receptor binding studies indicate that these amides demonstrated weak binding affinity at the phencyclidine (PCP) site on the $N$-methyl- $D$-aspartate (NMDA) receptor complex; however, a correlation between affinity and seizure protection in the MES test was not observed. Using $N$-(2,6-dimethyl)phenyl2-piperidinecarboxyamide 35 and $N(\alpha$-methylbenzyl)-2piperidinecarboxamide 36 as structural leads (Fig. 13), a variety of analogues have been synthesized and evaluated for anticonvulsant activity in the MES test in mice [87]. The following modifications led to an increase in MES activity: replacement of the piperidine ring with pyridine and movement of the carboxamide group to the 4-position, then opening the piperidine ring. The 2,6-dimethylanilides were the most potent compounds in the MES test in each group of compounds (Fig. 14). The 4-pyridinecarboxamide $37\left(\mathrm{ED}_{50}\right.$<smiles>Cc1cccc(C)c1NC(=O)C1CCCCN1</smiles>

35<smiles>C[C@H](NC(=O)C1CCCCN1)c1ccccc1</smiles>

36
Fig. (13). Structures of 2-piperidinecarboxamides with activity against MES in mice. 


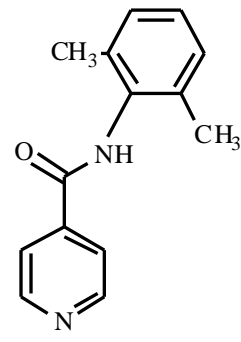

37

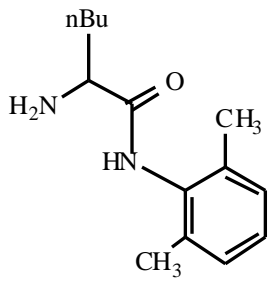

38
Fig. (14). Structures of 2,6-dimethylanilides, derivatives of carboxamides.

$=9.7 \mathrm{mg} \mathrm{kg}^{-1}, \mathrm{TD}_{50}=53.3 \mathrm{mg} \mathrm{kg}^{-1}, \mathrm{PI}=5.5$ ) was highly active in the MES test in mice. The norleucine derivative 38, obtained by opening the piperidine ring between the 1- and 6-positions was among the most potent compounds in the MES test in these series of compounds $\left(\mathrm{ED}_{50}=5.8 \mathrm{mg} \mathrm{kg}^{-1}\right.$, $\mathrm{TD}_{50}=36.4 \mathrm{mg} \mathrm{kg}^{-1}, \mathrm{PI}=6.3$ ). In these derivatives, the lipophilicity of the compound and the substitution at the $\alpha$ position of the amino acid derivative played key roles in quantitative anticonvulsant activity. Pyridinecarboxamide 37 and norleucinecarboxamide $\mathbf{3 8}$ were selected as useful leads in the development of compounds with therapeutic potential in the treatment of tonic-clonic and partial seizures in humans.

\section{Hydroxyamides}

Brown and coworkers have evaluated a series of novel hydroxyamides [88, 89]. Anticonvulsant testing of these compounds revealed the lead, 3,3,3-trifluoro-2-hydroxy-2phenyl-propionamide 39, to have potent anticonvulsant activity. Anticonvulsant evaluation of compound 39 administered i.p. in mice demonstrated complete (3/3 mice) protection at a dosage of $100 \mathrm{mg} \mathrm{kg}^{-1}$ up to $4 \mathrm{~h}$ when challenged with MES. Compound 39 also demonstrated effectiveness against scPTZ (5/5 mice protected) for $0.5 \mathrm{~h}$ at the same dosage. In rats p.o. test compound 39 protected: the MES $\mathrm{ED}_{50}$ value was found to be $9.9 \mathrm{mg} \mathrm{kg}^{-1}$, the $\mathrm{scPTZ}$ $\mathrm{ED}_{50}$ was $34 \mathrm{mg} \mathrm{kg}^{-1}$ and the $\mathrm{TD}_{50}$ noted at $100 \mathrm{mg} \mathrm{kg}^{-1}$, yielding a therapeutic index of 10 for the MES model and 2.6 for the scPTZ model. In this new series of compounds, two, 40 and 41, were the most active. Analogue 41's MES $\mathrm{ED}_{50}$ was also determined to be $62.4 \mathrm{mg} \mathrm{kg}^{-1}$ but has notably longer-lasting effects (up to $6 \mathrm{~h}$ ) and a $\mathrm{TD}_{50}$ over $100 \mathrm{mg}$ $\mathrm{kg}^{-}$. Patch clamp electrophysiology studies demonstrated significant tonic blockade of T-type calcium current by compounds 39-41 at 1mM. Furthermore, compounds 39 and 40 induced a significant use-dependent blockade of T-type calcium current. These results suggest that the mechanism of anticonvulsant activity may include blockade of T-type calcium currents. Compounds $\mathbf{4 0}$ and $\mathbf{4 1}$ are methylated versions of compound $\mathbf{3 9}$ at the amide and alcohol, respectively (Fig. 15). Summing up, compound 39 is an active orally available anticonvulsant with similar activity to phenytoin, and its methylated alcohol and amide have shown similar activity.<smiles>NC(=O)C(O)(c1ccccc1)C(F)(F)F</smiles><smiles>CNC(=O)C(O)(c1ccccc1)C(F)(F)F</smiles>

40<smiles>COC(C(N)=O)(c1ccccc1)C(F)(F)F</smiles>

41

Fig. (15). Derivatives of hydroxyamides.

\section{Alkanolamides}

In the group of alkanolamides (42), the most interesting results were yielded by $2-N$-methylaminoethanol derivative (compound 43), which displayed anti-MES activity (i.p. in mice) with a PI of $2.54\left(\mathrm{ED}_{50}\right.$ of $\left.51.8 \mathrm{mg} \mathrm{kg}^{-1}\right)$, higher than that for valproate $\left(\mathrm{ED}_{50}=287\right.$, PI 1.7) in the same test (Fig. 16) $[90]$.

<smiles>CN(CCO)OC(=O)c1ccc(OCc2ccccc2)cc1</smiles>

Fig. (16). Derivatives of 4-(benzyloxy)benzamides.

\section{HETEROCYCLIC AGENTS}

\section{(Arylalkyl)imidazoles}

One of the structurally distinct classes of antiepileptic drugs is the (arylalkyl)imidazoles. Denzimol (+/-)-N$[\beta-[4(\beta$-phenylethyl)phenyl]- $\beta$-hydroxyethyl]imidazole and nafimidone (1-[2-naphthoylmethyl)imidazole are examples of a class of anticonvulsants; the (arylalkyl)imidazoles (Fig. 17) [10]. SAR studies show that anticonvulsant properties of this group are associated with the presence of a small oxygen functional group (such as carbonyl, ethylene dioxy, methoxy, acyloxy and hydroxyl substituents) in the alkylene bridge in addition to an imidazole ring and a lipophilic aryl portion facilitating penetration of the blood barrier. The introduction of oxime and oxime ether groups to the alkylene bridge of (arylalkyl)imidazole as a small oxygen functional group led to new compounds, which displayed various levels of 


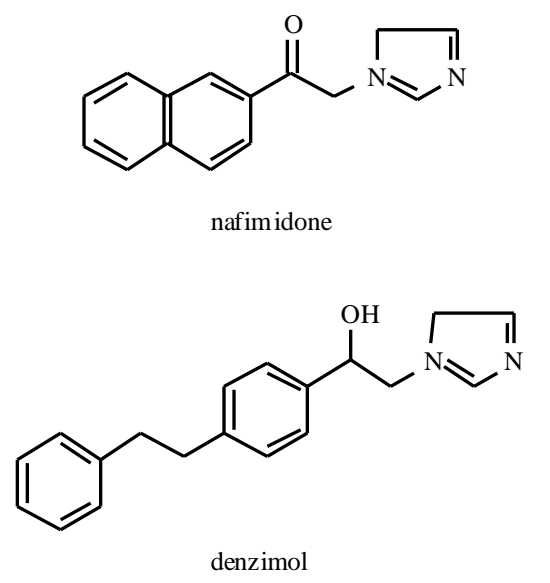

Fig. (17). Structures of (arylalkyl)imidazoles antiepileptic drugs.

activity [91]. Nafimidone oxime did not exhibit any anticonvulsant activity. $O$-Alkylation of nafimidone oxime, i.e. addition of an oxime ether functional group to the alkylene bridge of nafimidone, resulted in new compounds possessing anticonvulsant properties. The size of the alkyl moiety on the oxime group appears to be important for these properties. The $O$-alkyl substituted compounds (44-45) were found to be more active than the $O$-arylalkyl substituted compounds (Fig. 18). Anticonvulsant activity against MESinduced convulsion showed that compound $44 E$ (trans) isomer, was the most active with $\mathrm{ED}_{50} 17.95 \mathrm{mg} \mathrm{kg}^{-1}$ and $\mathrm{TD}_{50}<150$ when the drug was administered i.p. in rats. Compound 44 and 45 showed $\mathrm{ED}_{50}$ values of 46.77 and $36.99 \mathrm{mg} \mathrm{kg}^{-1}$ i.p. and $\mathrm{PI}=1.417$ and 1.411 respectively in MES test in mice.

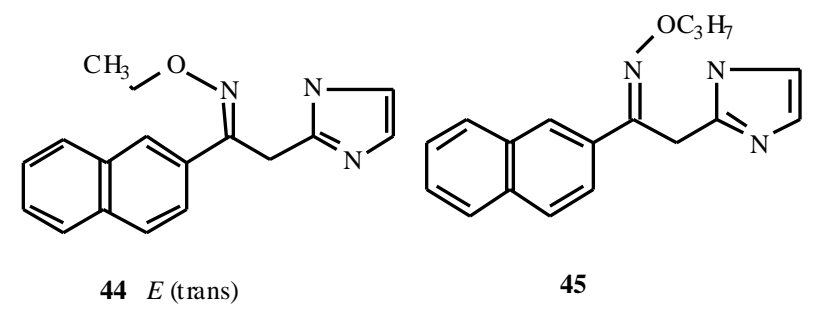

Fig. (18). Oxime ether derivatives 44-45 of anticonvulsant nafimidone.

\section{Pyrrolidin-2,5-diones}

Ethosuximide, a derivative of pyrrolidin-2,5-dione, belong to a group of old antiepileptic drugs and is still used in the treatment of epilepsy.

A great number of 3-phenylpyrrolidine-2,5-dione derivatives with pyridyl-, aryl- and aminophenyl-moiety at the nitrogen atom, as well as 3-arylpyrrolidine-2,5-dione containing a 4-arylpiperazinyl-1-yl-alkyl moiety at the nitrogen atom and 2-aza-spiro[4.4]nonane-1,3-dione have been investigated by Obniska, Zejc and coworkers [92-96]. Pharmacological studies have shown anticonvulsant activity in some compounds of that group. Recently, the most potent in the series of $\mathrm{N}$-[(4-arylpiperazin-1-yl)methyl derivatives of 3-arylpyrrolidine-2,5-dione were compounds 46 and 47
(Fig. 19). In the MES test in rats (after p.o. administration) the best $\mathrm{ED}_{50}=14.18 \mathrm{mg} \mathrm{kg}^{-1}$ and $\mathrm{PI}=8.8$ were recorded for compound 46. Compound 47 was less active, with $\mathrm{ED}_{50}=$ $133.64 \mathrm{mg} \mathrm{kg}^{-1}$ and PI $=2.47$.

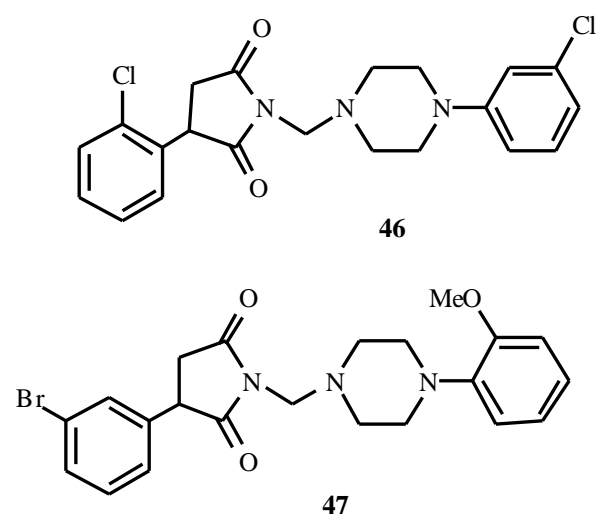

Fig. (19). Derivatives of 3-arylpyrrolidine-2,5-dione.

SAR studies in this group of pyrrolidin-2,5-dione derivatives have led to a conclusion that the following structural elements are required for anticonvulsant activity: an aromatic ring at the 3-position of pyrrolidine-2,5-dione moiety and a 4-arylpiperazine fragment with selected substituents at the phenyl ring. The introduction of a spirocyclopentyl ring at the 3-position of pyrrolidine-2,5dione did not enhance the anticonvulsant activity.

\section{Lactams}

Derivatives of cyclic lactams were synthesized and evaluated for antiepileptic activity [97-100]. One of the compounds, $\alpha$-hydroxy- $\alpha$-phenylcaprolactam (48) was particularly interesting. I.p. administration of $\mathbf{4 8}$ in mice, resulted in potent anticonvulsant protection in both anticonvulsant models tested (MES- and scMet-induced convulsions), exhibiting an anti-MES ED $\mathrm{ED}_{50}=63 \mathrm{mg} \mathrm{kg}^{-1}$ and anti-scMet $\mathrm{ED}_{50} 74 \mathrm{mg} \mathrm{kg}^{-1}$. New synthesized analogues of this compound, $\alpha$-benzyl- $\alpha$-hydroxycaprolactam (49), $\alpha$ ethynyl- $\alpha$-hydroxycaprolactam (50) and $\alpha$-hydroxy- $\alpha$ (phenylethynyl)caprolactam (51) (Fig. 20) displayed significant anticonvulsant activity [100]. For these compounds (i.p. in mice) anti-MES activity was seen at 100 $\mathrm{mg} \mathrm{kg}{ }^{-1}$ for 49, anti-scMet at $300 \mathrm{mg} \mathrm{kg}^{-1}$ for $\mathbf{5 0}$ and antiMES and anti-scMet at $100 \mathrm{mg} \mathrm{kg}^{-1}$ for 51. Compound 49 exhibited (oral activity in rats) an anti-MES $\mathrm{ED}_{50}=86 \mathrm{mg}$ $\mathrm{kg}^{-1}$ and anti-scMet $\mathrm{ED}_{50}<83 \mathrm{mg} \mathrm{kg}^{-1}$. Given that the Rotorod $\mathrm{TD}_{50}$ was greater than $330 \mathrm{mg} \mathrm{kg}^{-1}$, this particular lactam exhibited therapeutic indices exceeding 3.9 (MES) and 4.0 (scMet). These results showed that $\alpha$-benzyl- $\alpha$ hydroxycaprolactam (49) was effective in halting seizures, while $\alpha$-ethynyl- $\alpha$-hydroxycaprolactam (50) was a selective inhibitor of petite mal seizures. Compound $\mathbf{5 1}$ protected rats against MES-seizures at $30 \mathrm{mg} \mathrm{kg}^{-1}$; no toxicity was noted. The difference in activity between $\mathbf{5 0}$ and $\mathbf{5 1}$ was postulated to be a result, at least partly, of the significant change in log $P$ from the unsubstituted terminal alkyne $(-0.27)$ to the phenyl-substituted alkyne (1.52). The potent activity of 51 in all models indicated that the substituted alkynylcaprolactams represent a new anticonvulsant structural class. 


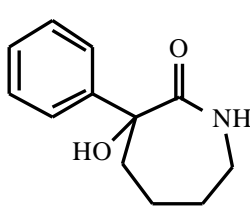

48

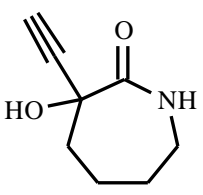

50

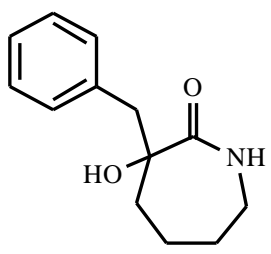

49

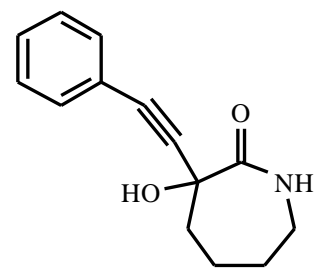

51
Fig. (20). Derivatives of $\alpha$-substituted caprolactams.

\section{Semi- and Thiosemicarbazones}

Semicarbazones and related compounds have a documented and consistent role in the design of novel anticonvulsant agents, through the work of Dimmock's and Pandeya's research group [101-112]. A number of semicarbazones, thiosemicarbazones, bis-carbohydrazones, aryl, arylidene, aryloxyaryl semicarbazones, acetylhydrazones and oxamoylhydrazones have been synthesized and evaluated for anticonvulsant activity. Extensive SAR studies have led to postulating a specific binding site of semicarbazones. The proposed pharmacophoric requirements in the semicarbazone molecules are: 1) aryl binding site with a hydrophobic group; 2) hydrogen bonding domain exemplified by the presence of the -NHCO-grouping; 3) two electron donor systems; 4) hydrophobic binding site whose size determines the type of activity.

Derivatives of (aryloxy)aryl semicarbazones displayed greater protection in the MES test than the scPTZ screen [103]. Quantification of approximately one-third of over 100 compounds tested revealed an average protection index of approximately 9. Following oral administration to rats, a number of compounds displayed significant potencies in the MES screen $\left(\mathrm{ED}_{50}\right.$ value of $\left.1-5 \mathrm{mg} \mathrm{kg}^{-1}\right)$ accompanied by a very high protection index. Later studies enabled the selection, in the series of aryloxyaryl semicarbazones, of a lead molecule 52 (Fig. 21). ED $_{50}$ values of compound 52 in the MES and scPTZ screens (i.p. in mice) were 48.6 and 94.1 $\mathrm{mg} \mathrm{kg}^{-1}$, with PI figures of 4.20 and 2.17 respectively [104]. Recently, compound 53 [4-(6-chlorobenzothiazol-2-yl)-1-(3isatinimino)thiosemicarbazone] has also shown strong activity in MES seizures and scPTZ screens [111]. Knowing that isatine derivatives possess anticonvulsant properties [113,114], compound $\mathbf{5 3}$ was designed as hybrid molecule incorporating a thiosemicarbazone fragment and an isatine molecule. Compound $\mathbf{5 3}$ was more potent than valproate against MES and scPTZ tests and was more effective than ethosuximide against MES-induced seizures, with an $\mathrm{ED}_{50}$ of 17.86 and $6.07 \mathrm{mg} \mathrm{kg}^{-1}$ i.p. in mice and rat p.o., respectively. Compound 53 exhibited a PI value of 8.77 in the rat p.o.

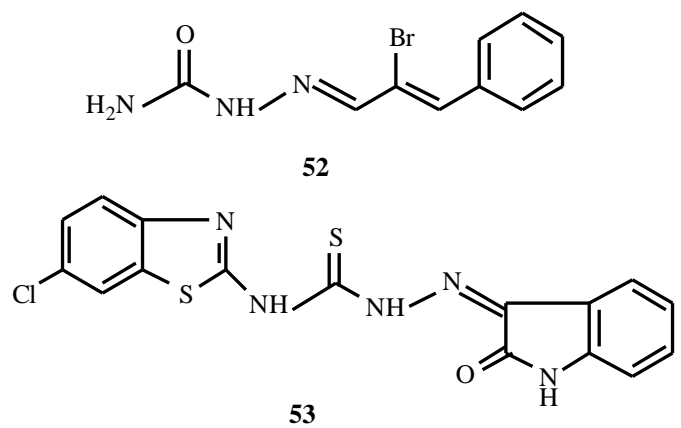

Fig. (21). Structures of semi- and thiosemicarbazones.

identification in the MES screen. In the preliminary hippocampal-kindling screen in rats (i.p.), compound $\mathbf{5 3}$ showed weak ability to block the expression of fully kindled seizures. The potency and spectrum of activity of these 6chlorobenzothiazolyl thiosemicarbazones were comparable to those of standard drugs, and represent a structurally novel class for subsequent molecular modifications.

\section{Thiadiazoles and Quinazolin-4(3H)-ones}

New thiadiazolyl and thiazolidinonyl quinazolin-4(3H)ones have been synthesized and screened for their anticonvulsant activity comparing with the standard AEDs [115]. These hybrid molecules comprise two fragments, quinazolinone and thiazolidinone, whose derivatives have been found to show anticonvulsant properties [116]. Out of the 30 new hybrid compounds, the most active was $\mathbf{5 4}$ (Fig. 22). Compound 54 at three graded doses of 7.5, 15 and 30 $\mathrm{mg} \mathrm{kg}^{-1}$ (i.p. in mice) in MES models was found to possess more potency than phenytoin and to be equipotent to lamotrigine at all the three dosage levels. In the scPTZ model, compound $\mathbf{5 4}$ exhibited better anticonvulsant activity than sodium valproate at all the three tested dosages (18.5, 37 and $74 \mathrm{mg} \mathrm{kg}^{-1}$ ). SAR studies have indicated that compounds having a 3-amino-2-methyl-6-bromoquinazolin$4(3 H)$-aryl moiety showed more protection than compounds with a 3-amino-2-methyl-quinazolin-4(3H)-aryl moiety.

Another group of new hybrid molecules represent derivatives of 1,3,4-thiadiazoles has been obtained by adding two heterocyclic nuclei possessing anticonvulsant activity, namely barbituric acid and quinazolinone (Fig. 22) [117]. Of the compounds studied, the most active one (55) displayed activity against MES and scPTZ seizure test in mice (i.p.) that was more potent than the standard drug. Compound $\mathbf{5 5}$ at three graded dosages of 17.5, 25 and $50 \mathrm{mg} \mathrm{kg}^{-1}$ has been found to incur 20, 40 and $90 \%$ protection in the MES model and 20,50 and $90 \%$ protection against seizure in the scPTZ model (respectively).

In the series of 2,5-disubstituted 1,3,4-thiadiazoles, two active anticonvulsant agents $(\mathbf{5 6}, \mathbf{5 7})$ have been found [118]. Compounds 56 and $\mathbf{5 7}$ have shown maximum protection (90 and $70 \%$, respectively) comparative to sodium valproate $(80 \%)$ in the scPTZ screen. The $\mathrm{ED}_{50}$ values of the most effective compounds 56 and 57 were 33 and $66 \mathrm{mg} \mathrm{kg}^{-1}$ respectively (Fig. 23). 
<smiles>[X]c1ccc2c(=O)n(NCc3nnc([R])s3)c(C)nc2c1</smiles>

$\mathrm{R}=$ $\mathrm{X}=6,7 \mathrm{di}-\mathrm{Br}$<smiles>COc1cc(C2CN(C)C(=O)S2)ccc1O</smiles>

54<smiles>CNCC1C(=O)NC(=S)NC1=O</smiles>

Fig. (22). Derivatives of thiadiazolyl quinazolin-4(3H)-ones.<smiles>[R]Nc1nnc(-c2ccccc2O)s1</smiles>

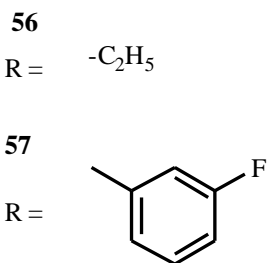

Fig. (23). 2,5-Disubstituted 1,3,4-thiadiazoles.

\section{Xanhtones}

A different group of substituted derivatives of xanthone as new anticonvulsant agents has been discovered by Marona and coworkers [119-123]. A series of alkanolamides, alkanoamines and aminoalkanolic derivatives of 2-, 3-, 6-, 7xanthone have been obtained and evaluated for anticonvulsant activity in the MES and scPTZ assays. Several compounds have been found to be active in both anticonvulsant tests. In a series of aminoisopropanoloxy derivatives of 2-, 3-, or 6-xanthone, the most promising compounds were the 3-(tert-buthyl-amino) (58) and 3-[Nmethyl-(tert-buthyl)-amino] (59) substituted 2-hydroxy-1-(2xanthonoxy)-propane and compound 60 [122], of which 59 was active in both anticonvulsant tests [119] (Fig. 24). Results of quantitative anticonvulsant activity in the MES screen (i.p. in mice) for the tested compounds were as follows: for $58 \mathrm{ED}_{50}=42.2 \mathrm{mg} \mathrm{kg}^{-1} \mathrm{PI}=1.9$, for $59 \mathrm{ED}_{50}=$ $110.0 \mathrm{mg} \mathrm{kg}^{-1} \mathrm{PI}>4.5$, for $60 \mathrm{ED}_{50}=173.45 \mathrm{mg} \mathrm{kg}^{-1} \mathrm{PI}=$ 0.80 .

In a series of alkanolamides and alkanoamines [120, 121] 2-amino- or 2- $\mathrm{N}$-methylamino-1-butanol and derivatives of 7-chloroxanthone $(\mathbf{6 1}, \mathbf{6 2})$ have been found active in both anticonvulsant tests, displaying anti-MES activity (i.p. in mice) with a PI in the range of 2.84-3.64 corresponding with that for phenytoin, carbamazepine and valproate. In the MES test, both racemate $62(R, S)$ and $62(R)$ isomer displayed activity in the similar range $\left[\mathrm{ED}_{50}=27 \mathrm{mg} \mathrm{kg}^{-1} \mathrm{PI}=3.28\right.$ for $62(R, S)$ and $\mathrm{ED}_{50}=33.4 \mathrm{mg} \mathrm{kg}^{-1} \mathrm{PI}=2.848$ for $\left.62(R)\right]$.

Among derivatives of 6-methoxy- or 6-chloroxanthone, the most active were 2-amino-1-propanol-, 1-amino-2propanol- and 1-amino-2-butanol derivatives, which displayed anti-MES activity with a PI in the range of 2,215.88. In the MES test (i.p. in mice), $\mathrm{ED}_{50}$ values were 33.89 , $37.4,41.2$ and $56.2 \mathrm{mg} \mathrm{kg}^{-1}$ for compounds $\mathbf{6 3}(R, S), \mathbf{6 3}(S)$,
$64(R, S)$ and $65(R, S)$ respectively [121]. Recent studies of some central effects of chiral xanthone derivatives demonstrated differing potencies of enantiomers and a racemic mixture of compound 65 [123].

\section{Derivatives of Isatin}

Derivatives of 1,3-dihydro-indol-2-one (isatin) have been reported to possess anticonvulsant activity [113, 114]. Recent studies of hydrazones, Schiff and Mannich, bases of isatin, have led to the discovery of a new anticonvulsant agent (66) effective in both MES and scPTZ tests [124-126] (Fig. 25). Compound 66 [3-(4-chloro-phenylimino)-5methyl-1,3-dihydro-indol-2-one] yielded $87 \%$ protection at $100 \mathrm{mg} \mathrm{kg}^{-1}$ with an $\mathrm{ED}_{50}$ value of $53.61 \mathrm{mg} \mathrm{kg}^{-1}$ in the scPTZ screen after i.p. administration in mice. This new agent was less neurotoxic than phenytoin, and showed greater protection than sodium valproate [124].

\section{MISCELLANEOUS STRUCTURES}

\section{Enaminones}

Scott and coworkers have synthesized a series of enaminones bearing the aniline, benzylamine moieties and various aromatic heterocycles such as the pyridine, phenothiazines, and currently the isoxazole nucleus [127134]. The prototype compound in the aniline series of enaminone was methyl 4-[(4-chlorophenyl)amino]-6-methyl2-oxo-3-cyclohexene-1-carboxylate (67). Their ethyl analogue (68) was found to be the most promising enaminone in the aniline series in both rat and mouse models during preliminary pharmacological evaluation (Fig. 26). In MES model seizures, in mice, i.p. administration of $\mathbf{6 8}$ resulted in an $\mathrm{ED}_{50}$ value of $16.7 \mathrm{mg} \mathrm{kg}^{-1}$ and $\mathrm{TD}_{50}$ of 110.7 $\mathrm{mg} \mathrm{kg}^{-1}, \mathrm{PI}=6.6$ and an $\mathrm{ED}_{50}$ value of $3.0 \mathrm{mg} \mathrm{kg}^{-1}$ and $\mathrm{TD}_{50}$ $>250 \mathrm{mg} \mathrm{kg}^{-1}$, PI = 83.3 p.o. administration in rats. 
<smiles>[R]CC(O)COc1ccc2oc3ccccc3c(=O)c2c1</smiles><smiles>[R]Cc1ccc2oc3ccc(Cl)cc3c(=O)c2c1</smiles><smiles>Cc1ccc2oc3cc(OCC(O)CNC(C)C)ccc3c(=O)c2c1</smiles><smiles>[R]Cc1ccc2oc3cc([X])ccc3c(=O)c2c1</smiles>
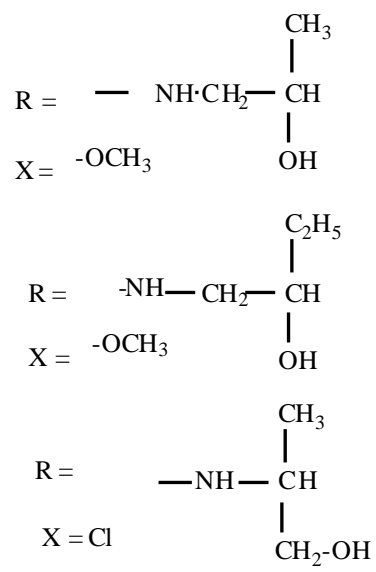

Fig. (24). Derivatives of xanthone.

Compound 68 was more potent than phenytoin, however it was proposed that the enaminones possessed an anticonvulsant profile similar to phenytoin. Compound $\mathbf{6 8}$ was then evaluated for sodium channel binding activity. It provided a statistically significant block $(\mathrm{P}<0.05)$ at $-60 \mathrm{mV}$, however the blockade was not strong enough to conclude that this was its principal mechanism of action. A biotransformation pathway for enaminones was also investigated [134]. The pharmacokinetic evaluation of $\mathbf{6 8}$ indicated that the carboalkoxy substituent converted in a two step reaction involving deesterification and decarboxylation to a second active enaminone metabolite 69 (Fig. 27). The 5methyl ketone (69) in the MES screens displayed an an $\mathrm{ED}_{50}$ value of $40.4 \mathrm{mg} \mathrm{kg}^{-1}$ and $\mathrm{TD}_{50}$ of $93.6 \mathrm{mg} \mathrm{kg}^{-1}, \mathrm{PI}=2.3$, TPE 0.25 in mice, i.p. and in rats p.o. an $\mathrm{ED}_{50}$ value of 14.7 $\mathrm{mg} \mathrm{kg}{ }^{-1}$ and $\mathrm{TD}_{50}>186 \mathrm{mg}^{-1}$, PI = 12.7, TPE 1.6.<smiles>Cc1ccc2c(c1)/C(=N/c1ccc(Cl)cc1)C(=O)N2</smiles>

Fig. (25). Schiff base of isatin.

The anticonvulsant activity of a series of enaminonederived isoxazoles provided a potent, orally active class of compounds [131]. Two series of enaminones possessing the isomeric 5-methyl-substituted isoxazoles and 3- methylsubstituted isoxazoles revealed both similarities and differences with regard to anticonvulsant activity (Fig. 28). The most potent anti-MES were three compounds in the 3amino series: ethyl ester 70 (ethyl 4-(5-methyl-3-isoxazolyl) amino]-6-methyl-2-oxo-3-cyclohexene-1-carboxylate), $\mathrm{ED}_{50}$ $68.9 \mathrm{mg} \mathrm{kg}^{-1}$, p.o. in rats $\mathrm{TD}_{50}>500 \mathrm{mg} \mathrm{kg}^{-1}$, PI > 49.6; methyl ester (71), $\mathrm{ED}_{50} 68.9 \mathrm{mg} \mathrm{kg}^{-1}$ i.p. in mice, $\mathrm{TD}_{50}>500$ $\mathrm{mg} \mathrm{kg}^{-1}$, PI > 7.3, and tert-buthyl ester (72), ED $5028.1 \mathrm{mg}$ $\mathrm{kg}^{-1}$ p.o. in rats, $\mathrm{TD}_{50}>500 \mathrm{mg} \mathrm{kg}^{-1}$, PI > 17.8. Sodium channel binding studies, as well as evaluations against pentylenetetrazol, bicuculline, and picrotoxin on izoxazole 70 were all negative, leading to an unknown mechanism of action. X-ray diffraction patterns of a representative of the 3amino series of isoxazoles displayed the existence of intramolecular hydrogen bonding of nitrogen to the vinylic proton in the cyclohexane ring, providing a pseudo-three ring<smiles>[X]OC(=O)C1C(=O)C=C(Nc2ccc(Cl)cc2)CC1C</smiles>

$67 \quad \mathrm{R}=\mathrm{CH}_{3} \quad 68 \quad \mathrm{R}=\mathrm{C}_{2} \mathrm{H}_{5}$

Fig. (26). Structures of anticonvulsant enaminones. 


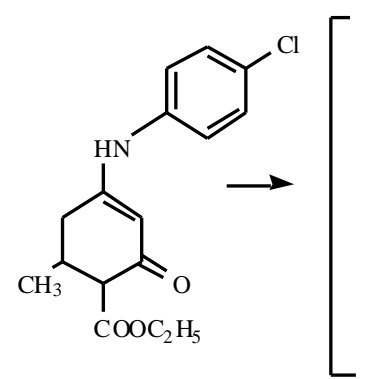

68

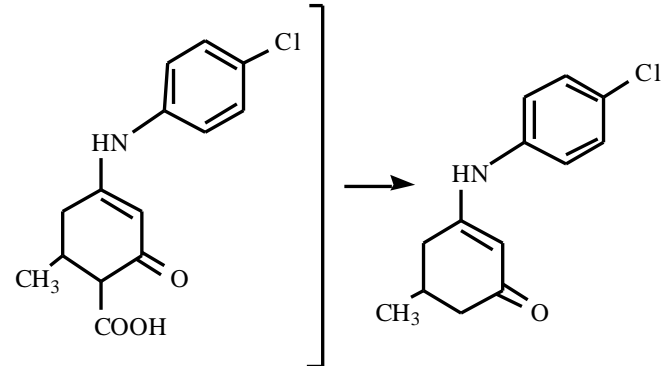

69

Fig. (27). A biotransformation pathway of enaminone 68 .<smiles></smiles>

70<smiles>[R]OC(=O)C1C(=O)C=C(Nc2cc(C)on2)CC1C</smiles>

$71 \mathrm{R}=$ methyl, $72 \mathrm{R}=$ tert -buthyl

Fig. (28). The isoxazolylamino enaminones.

structure which was also detected previously in vinylic benzamides. According to the authors, the activity-inactivity of the 3-amino and 5-amino, isoxazoles may be due to the orientation of the pseudo-three ring system.

\section{SUMMARY}

The presented review summarizes ongoing medicinal chemistry investigations in search for new anticonvulsant compounds. Many of the compounds presented in this review have been evaluated by the ADD Program. Their anticonvulsant activity has been confirmed through in vivo screening tests, although for many compounds the precise mechanism of action is still not known. Some of the newer anticonvulsant agents represent structural modifications of pre-existing compounds, while others have been developed with the specific objective of modifying targets. These new agents belong to several different chemical classes. Some of them represent compounds bearing five-membered or other heterocyclic rings in their structure; additionally, numerous studies have demonstrated that derivatives of amino acids can function as potential new anticonvulsant agents. The most common structural elements of many active compounds are an amide bond (particularly a benzylamide group) and the presence of at least one aryl unit. New data has also confirmed that the lipophilicity of new active molecules is an important factor affecting their anticonvulsant potency. These new agents can be used for the design of future targets and development of new drugs. The discovery of a number of active leads may also ultimately help elucidate the mechanism of action of these new anticonvulsants.

\section{ABBREVIATIONS}

AED $\quad=$ Antiepileptic drug

\begin{tabular}{|c|c|c|}
\hline ASP & $=$ & The Anticonvulsant Screening Project \\
\hline $\begin{array}{l}\text { ADD } \\
\text { program }\end{array}$ & $=$ & Antiepileptic Drug Development program \\
\hline MES & $=$ & Maximal electroshock \\
\hline scPTZ & $=$ & Subcutaneous pentylenetetrazole \\
\hline scMet & $=$ & Subcutaneous metrazol \\
\hline GABA & $=$ & $\gamma$-aminobutyric acid \\
\hline THIQ & $=$ & Tetrahydroisoquinoline \\
\hline MEST & $=$ & Maximal electroshock threshold \\
\hline $\mathrm{ED}_{50}$ & $=$ & The median effective dose \\
\hline $\mathrm{TD}_{50}$ & $=$ & The median toxic dose \\
\hline PI & $=$ & Protective index \\
\hline PI & $=$ & $\mathrm{TD}_{50} / \mathrm{ED}_{50}$ \\
\hline $\mathrm{CA}$ & $=$ & Carbonic anhydrase \\
\hline $\mathrm{hCA}$ & $=$ & Human cloned isoenzymes \\
\hline i.p & $=$ & Intraperitoneally \\
\hline p.o. & $=$ & Orally \\
\hline $\mathrm{BIC}$ & $=$ & Bicuculline \\
\hline PCR & $=$ & Picrotoxin \\
\hline SAR & $=$ & Structure-activity-relationships \\
\hline FAA & $=$ & Functionalized amino acid \\
\hline FAK & $=$ & Functionalized amindo ketones \\
\hline AAA & $=$ & Amino acid amides: \\
\hline
\end{tabular}


AMPA $=\alpha$-amino-3-hydroxy-5-methyl-4isoxazolepropionic acid

NMDA $=N$-methyl- $D$-aspartate

\section{REFERENCES}

[1] Bell, G.S.; Sander, J.W. The epidemiology of epilepsy: The size of the problem. Seizure 2002, 11 (Suppl. A), 306-314.

[2] Lopes Lima, J.M. The new drugs and strategies to manage epilepsy. Curr. Pharmac. Design 2000, 6, 873-878.

[3] Perucca, E. Marketed new antiepileptic drugs: Are they better than old-generation agents ? Ther. Drug Monit. 2002, 24, 74-80.

[4] Berk, M.; Segal, J.; Janet, L.; Vorster, M. Emerging options in the treatment of bipolar disorders. Drugs 2001, 61, 1407-1414.

[5] Duncan, J.S. The promise of new antiepileptic drugs. Br. J. Clin. Pharmacol. 2002, 53, 123-131.

[6] Eadie, M.J. Can anticonvulsant drug therapy 'cure' epilepsy? CNS Drugs 2001, 15, 679-690.

[7] Szelenyi, I.; Horvath, K.; Howes, J.F.; Mazarati, A.M. The treatment of epilepsy: future possibilities. Drugs Fut. 2003, 28, 925-936.

[8] Bruno-Blanch, L.; Gálvez, J.; García-Domenech, R. Topological virtual screening: A way to find new anticonvulsant drugs from chemical diversity. Bioorg. Med. Chem. Lett. 2003, 13, 2749-2754.

[9] Malawska B.: Application of pharmacophore models for the design and synthesis of new anticonvulsant drugs. Mini Rev. Med. Chem. 2003, 3, 341-348.

[10] Edafiogho, I.; Scott, K.R. Anticonvulsants. Burger's Medicinal Chemistry and Drug Discovery, Fifth Ed. Vol. 3: Therapeutic Agents, Ed. Wolff, M.E. John Wiley \& Sons, Inc, 1996, 175-260.

[11] Cosford, N.D.P.; Meinke, P.T.; Stauderman, K.A.; Hess, S.D. Recent advances in the modulation of voltage-gated ion channels for the treatment of epilepsy. Curr. Drug Targ.CNS \& Neur. Dis. 2002, $1,81-104$.

[12] Auberson, Y.P. Competitive AMPA antagonism: a novel mechanism for antiepileptic drugs ? Drugs Fut. 2001, 26, 463-471.

[13] Jansen, M.; Dannhardt, G. Antagonists and agonists at the glycine site of the NMDA receptor for therapeutic interventions. Eur. J. Med. Chem. 2003, 38, 661-670.

[14] Isaac, $\mathrm{M}$. The 5- $\mathrm{HT}_{2 \mathrm{C}}$ receptor as a potential therapeutic target for the design of antiobesity and antiepileptic drugs. Drugs Fut. 2001, 26, 383-393.

[15] Wiesner, J.B.; Ugarkar, B.G.; Castellino, A.J.; Barankiewicz, J.; Dumas, D.P.; Gruber, H.E.; Foster, A.C.; Erion, M.D. Adenosine kinase inhibitors as a novel approach to anticonvulsant therapy. $J$. Pharmacol. Exp. Ther. 1999, 289, 1669-1677.

[16] Zorumski, Ch.F.; Mennerick, S.; Isenberg, K.E.; Covey, D.F. Potential clinical uses of neuroactive steroids. Curr. Op. Invest. Drugs 2000, 1, 360-369.

[17] Czuczwar, S.J.; Patsalos, P.N. The new generation of GABA enhancers. CNS Drugs 2001, 15, 339-350.

[18] Gatti, G.; Bonomi, I.; Jannuzzi, G.; Perucca, E. The new antiepileptic drugs: Pharmacological and clinical aspects. Curr. Pharm. Design 2000, 6, 839-860.

[19] Nicolson, A.; Leach, J.P. Future prospects for the drug treatment of epilepsy. CNS Drugs 2001, 15, 955-968.

[20] Patsalos, P.N. Ant-epileptic drugs: Newly licensed and under development. Curr. Op. Inv. Drugs 1999, 1, 549-562.

[21] Saxena, A.K.; Saxena, M. Development in anticonvulsants. Progress in Drug Research Ed. Jucker, E.Birkhäuser verlag Basel Boston Berlin 1995, 44, 185-291.

[22] Cosford, N.D.P.; McDonald, I.A.; Schweiger, E.J. Recent progress in antiepileptic drug research. In Annual Reports in Medicinal Chemistry; Robertson, Ed. Academic Press: 1998, 33, 61-70.

[23] Martin, L.; Rabasseda, X. ; Leeson, R.P.; Casta_er, J. Pregabalin. Drugs Fut. 1999, 24, 862-870.

[24] Hachad, H.; Ragueneau-Majlessi, I.; Levy, R.H. New antiepileptic drugs: Review on drug interactions. Ther. Drug Monit. 2002, 24, 91-103.

[25] Kupferberg, H.J. Antiepileptic drug development program: A cooperative effort of government and industry. Epilepsia 1989, 30, (suppl), S51-S56.
[26] Stables, J.P.; Kupferberg, H.J. National Institute of Neurological Disorders and Stroke. Anticonvulsant Screening Project Raport. Chapter 16. www. ninds.nih.gov/about_ninds/ anticonvulsant_ srceening_project.htm

[27] Schwabe, W.; Willmore, L.J. Losigamone. Curr. Op. Invest. Drugs 2001, 2, 1763-1766.

[28] Fatope, M.O. Soretolide. Curr. Op. Invest. Drugs 2001, 2, 824-827.

[29] Sorbera, L.A.; Leeson, P.A., Rabasseda, X.; Casta_er, J. Rufinamide. Drug Fut. 2000, 25, 1145-1149.

[30] Swinyard, E.A.; Woodhead, J.H.; White, H.S.; Franklin, M.R. General principles: experimental selection, quantification, and evaluation of anticonvulsants. In: Antiepileptic Drugs, Third Edition Levy, R.H.; Mattson, R.H.; Meldrum, B.; Penry J.K.; Dreifuss, F.E. eds. New York: Raven Press 1989, 85-102.

[31] Snead, O.C. Pharmacological models of generalized absence seizures in rodents. J. Neural Transm. (Suppl) 1992, 35, 7-19.

[32] Blackburn, T.P.; Buckingham, R.E.; Chan, W.N.; Evans, J.M.; Hadley, M.S.; Thompson, M.; Upton, N.; Stean, T.O.; Stemp, G.; Vong, A.K. Stereochemical differentiation of anticonvulsant and antihypertensive effects in (4-fluorobenzoylamino)-benzopyrans. Bioorg. Med. Chem. Lett. 1995, 5, 1163-1166.

[33] Chan, W.N.; Upton, N.; Vong, A.K. Synthesis of novel trans-4(substituted-benzamido)-3,4-dihydro- $2 H$-benzo[b]pyran-3-ol derivatives as potential anticonvulsant agents with a distinctive binding profile J. Med. Chem. 1996, 39, 4537-4539.

[34] Herdon, H.J.; Jerman, J.C.; Stean, T.O.; Middlemiss, D.N.; Chan, W.N.; Vong, A.K.; Evans, J.M.; Thompson, M.; Upton, N. Characterization of the binding of [3H]-SB-204269, a radiolabelled form of the new anticonvulsant SB-204269 (carabersat), to a novel binding site in rat brain membranes. Brit. J. Pharmacol. 1997, 121, $1687-$

[35] Chan, W.N.; Hadley, M.S.; Harling, J.D.; Herdon, H.J.; Jerman, J.C.; Orlek, B.S.; Stean, T.O.; Thompson, M; Upton, N.; Ward, R.W. Identification of a series of 1,2,3,4-tetrahydroisoquinolinylbenzamides with potential anticonvulsant activity. Bioorg. Med. Chem. Lett. 1998, 8, 2903-2906.

[36] Chan, W.N.; Hadley, M.S.; Harling, J.D.; Herdon, H.J.; Orlek, B.S.; Riley, G.J.; Stead, R.E.A.; Stean, T.O.; Thompson, M.; Upton, N.; Ward, R.W. Evaluation of a series of anticonvulsant 1,2,3,4tetrahydroisoquinolinyl-benzamides. Bioorg. Med. Chem. 2000, 8, 2085-2094.

[37] Austin, N.E.; Hadley, M.S.; Harling, J.D.; Harrington, F.P.; Macdonald G.J.; Mitchell, D.J.; Riley, G.J.; Stean, T.O.; Stemp, G.; Stratton, S.C.; Thompson, M.; Upton, N. The design of 8,8dimethyl[1,6]naphthyridines as potential anticonvulsant agents. Bioorg. Med. Chem. Lett. 2003, 13, 1627-1629.

[38] Supuran, C.T.; Scozzafava, A. Carbonic anhydrase inhibitors. Curr. Med. Chem.- Imm., Endoc. \& Metab. Agents 2001, 1, 61-97.

[39] Shank, R.P.; Gardocki, J.F.; Vaught, J.L.; Davis, C.B.; Schupsky, J.J.; Raffa, R.B.; Dodgson, S.J.; Nortey, S.O.; Marianoff, B.E. Topiramate: preclinical evaluation of strucrally novel anticonvulsant. Epilepsia 1994 35, 450-460.

[40] Sabers, A.; Gram, L. Newer anticonvulsants: Comparative review of drug interactions and adverse effects. Drugs 2000, 60, 23-33.

[41] Supuran, C.T.; Mincione, F.; Scozzafava, A.; Briganti, F.; Mincione, G.; Ilies, M.A. Carbonic anhydrase inhibitors. Metal complexes of heterocyclic sulfonamides: A new class of strong topical intraocular pressure-lowering agents with potential use as antiglaucoma drugs. Eur.J. Med. Chem. 1998, 33, 247-254.

[42] Ilies, M.; Supuran, C.T.; Scozzafava, A.; Casini, A.; Mincione, F.; Menabuoni, L.; Caproiu, M.T.; Maganu. M.; Banciu, M.D. Carbonic anhydrase anhibitors. Sulfonamides incorporating furan-, thiophene- and pyrrole-carboxamido groups possess strong topical intraocular pressure lowering properties as aqueous suspensions. Bioorg. Med. Chem. 2000, 8, 2145-2155.

[43] Scozzafava, A.; Menabuoni, L.; Mincone, F.; Briganti, F.; Mincione, G.; Supuran, C.T. Carbonic anhydrase inhibitors. Perfluoroalkyl/aryl-substituted derivatives of aromatic/heterocyclic sulfonamides as topical intraocular pressure lowering agents with prolonged duration of action. J. Med. Chem. 2000, 43, 4542-4551.

[44] Casini, A.; Scozzafava, A.; Mincione. F.; Menabuoni, L.; Ilies, M.A.; Supuran. C.T. Carbonic anhydrase inhibitors. Water soluble 4-sulfamoylphenyl-thioureas as topical intraocular pressure lowering agents with long lasting effects. J. Med. Chem. 2000, 43, 4884-4892. 
[45] Masereel, B.; Rolin, S.; Abbate, F.; Scozzafava, A.; Supuran, C.T. Carbonic anhydrase inhibitors: Anticonvulsant sulfonamides incorporating valproyl and other lipophilic moieties. J. Med. Chem. 2002, 45, 312-320.

[46] Ilies, M.A.; Masereel, B.; Rolin, S.; Scozzafava, A.; Câmpeanu, G.; Cîmpeanu, V.; Supuran, C.T. Carbonic anhydrase inhibitors: aromatic and heterocyclic sulfonamides incorporating adamantyl moieties with strong anticonvulsant activity. Bioorg. Med. Chem. 2004, 12, 2717-2726.

[47] Conley, J.D.; Kohn, H. Functionalized DL-amino acid derivatives. Potent new agents for the treatment of epilepsy. J. Med. Chem. 1987, 30, 567-574.

[48] Kohn, H.; Conley, J.D.; Leander, J.D. Marked stereospecificity in a new class of anticonvulsants. Brain Res. 1988, 457, 371-375.

[49] Kohn, H.; Sawhney, K.N.; LeGall, P.; Conley, J.D.; Robertson, D.W.; Leander, J.D. Preparation and anticonvulsant activity of a series of functionalized $\alpha$-aromatic and $\alpha$-heteroaromatic amino acids. J. Med. Chem. 1990, 33, 919-926.

[50] Kohn, H.; Sawhney, K.N.; LeGall, P.; Robertson, D.W.; Leander, J.D. Preparation and anticonvulsant activity of a series of functionalized $\alpha$-heteroaromatic-substituted amino acids. J. Med. Chem. 1991, 34, 2444-2452.

[51] Kohn, H.; Sawhney, K.H.; Bardel, P.; Robertson, D.W.; Leander, J.D. Synthesis and anticonvulsant activities of $\alpha$-heteroaromatic- $\alpha$ acetamido-N-benzylacetamide derivatives. J. Med. Chem. 1993, 36, 3350-3360.

[52] Bardel, P.; Bolanos, A.; Kohn, H. Synthesis and anticonvulsant activities of $\alpha$-acetamido-N-benzylacetamide derivatives containing an electron-deficient $\alpha$-heteroaromatic substituent. J. Med. Chem. 1994, 37, 4567-4571.

[53] Kohn, H.; Sawhney, K.N.; Robertson, D.W.; Leander, J.D. Anticonvulsant properties of $\mathrm{N}$-substituted $\alpha, \alpha$-diamino acid derivatives. J. Pharm. Sci. 1994, 83, 689-691.

[54] Choi, D.; Stables, J.P.; Kohn, H. Synthesis and anticonvulsant activities of N-benzyl-2-acetamidopropionamide derivatives. $J$. Med. Chem. 1996, 39, 1907-1916.

[55] Andurkar, S.V.; Stables J.P.; Kohn, H. The anticonvulsant activities of N-benzyl-3-methoxypropionamides. Bioorg. Med. Chem. 1999, 7, 2381-2389.

[56] Le Tiran, A.; Stables, J.P.; Kohn, H. Functionalized amino acid anticonvulsants: Synthesis and pharmacological evaluation of conformationally restricted analogues. Bioorg. Med. Chem. 2001, 9 , 2693-2708.

[57] Andurkar, S.V.; Béguin, C.; Stables J.P.; Kohn, H. Synthesis and structural studies of aza analogues of funcionalized amino acids: New anticonvulsant agents. J. Med. Chem. 2001, 44, 1475-1478.

[58] Le Tiran, A.; Stables, J.P.; Kohn, H. Design and evaluation of affinity labels of functionalized amino acid anticonvulsants. J. Med. Chem. 2002, 45, 4762-4773.

[59] Shen, M.; Le Tiran, A.; Xiao, Y.; Golbraikh, A.; Kohn, H.; Tropsha, A. Quantitative structure-activity relationships analysis of funcionalized amino acid anticonvulsant agents using $\mathrm{k}$ nearest neighbor and simulated annealing PLS methods. J. Med. Chem. 2002, 45, 2811-2823.

[60] Béguin, C.; Andurkar, S.V.; Jin, A.Y.; Stables, J.P.; Weaver, D.F.; Kohn, H. Functionalized amido ketones: New anticonvulsant agents. Bioorg. Med. Chem. 2003, 11, 4275-4285.

[61] Béguin, C.; LeTiran, A.; Stables, J.P.; Voyksner, R.D. ; Kohn, H. $N$-Substituted amino acid N'-benzylamides: Synthesis, anticonvulsant, and metabolic activities. Bioorg. Med. Chem. 2004, 12, 3079-3096.

[62] Paruszewski, R.; Rostafi ńska-Suchar, G.; Strupi ńska, M.; Jaworski, P.; Stables, J.P. Synthesis and anticonvulsant activity of some amino amid derivatives. Part 1: Alanine derivatives. Pharmazie 1996, 51, 145-148.

[63] Paruszewski, R.; Rostafińska-Suchar, G.; Strupi ńska, M.; Jaworski, P.; Winiecka, I.; Stables, J.P. Synthesis and anticonvulsant activity of some amino amid derivatives. Part 2: Derivatives of Gly, Ala, Leu, Pro, Trp, Phe(4Cl), Ala( $\alpha$-Me). Pharmazie 1996, 51, 212-215.

[64] Paruszewski, R.; Rostafińska-Suchar, G.; Strupińska, M.; Winiecka, I.; Stables, J.P. Synthesis and anticonvulsant activity of some amino amid derivatives. Part 3: Derivatives of Ala. Arg, Tzl, Gly and



[65] Paruszewski, R.; Strupińska, M.; Stables, J.P.; Swiąder, M.; Czuczwar, S.; Kleinrock, Z.; Turski, W. Amino acid derivatives with anticonvulsant activity. Chem. Pharm. Bull. 2001, 49, 629631.

[66] Paruszewski, R.; Strupińska, M.; Rostafińska-Suchar, G.; Stables, J.P. Anticonvulsant activity of benzylamides of some amino acids and heterocyclic acids. Prot. Pept. Lett. 2003, 10, 475-482.

[67] Paruszewski, R.; Rostafińska-Suchar, G. Strupińska, M.; Stables, J.P. The Fourth Multidisciplinary Conferences on Drug Research, Gdańsk-Sobieszewo, Book of abstract, 2004, P-129.

[68] Kieć-Kononowicz, K.; Karolak-Wojciechowska, J; Handzlik, J. Glycine derivatives of imidazolones as potential ligands of glycine binding site of NMDA receptors. Acta Pol. Pharm.-Drug Res. 1998, 55, 381-388.

[69] Kieć-Kononowicz, K.; Karolak-Wojciechowska, J. Structure and activity studies on glycine receptor ligands. Diphenyl imidazolin-4one glycinamides. Acta Pol. Pharm.-Drug Res. 1998, 55, 389-397.

[70] Karolak-Wojciechowska, J.; Kieć-Kononowicz, K.; Mrozek. A. Structure and activity studies of glycine receptor ligands. Structural remarks on arylidene-imidazoline-4-one glycinates and glycinamides. J. Mol. Srtuct. 2001, 597, 73-81.

[71] Karolak-Wojciechowska, J.; Mrozek. A.; Kieć-Kononowicz, K.; Handzlik, J. Structure and activity studies of glycine receptor ligands. Arylidene-imidazoline-4-one aminoacids. J. Mol. Srtuct. 2003, 649, 25-36.

[72] Tan, C.Y.K.; Wainman, D.; Weaver, D.F. $N-, \alpha-$, and $\beta$-Substituted 3-aminopropionic acids: Design, syntheses and antiseizure activities. Bioorg. Med. Chem. 2003, 11, 113-121.

[73] Kim, Y.; Zhao, L.-X.; Kim, T.-H.; Je, S.; Kim, E.; Choi, H.; Chae, W.-G; Park, M.; Choi, J; Jahng, Y.; Lee, E.-S. Design and synthesis of anticonvulsive agents as $\gamma$-vinyl GABA-based potential dual acting prodrugs and their biological activities. Bioorg. Med. Chem. Lett. 2000, 10, 609-613.

[74] Zhao, L.-X.; Park, J.G.; Moon, Y.-S.; Basnet, A.; Choi, J.; Kim, E.; Jeong, T.C.; Jahng, Y.; Lee, E.-S. Design, synthesis and anticonvulsive activity of analogs of $\gamma$-vinyl GABA. Farmaco 2004, 59, 381-388.

[75] Malawska, B.; Gobaille, S. Synthesis, physicochemical and pharmacological properties of new $N$-substituted amides of $\alpha$ piperazine- $\gamma$-hydroxybutyric acid. Pharmazie 1995, 50, 390-393.

[76] Malawska, B.; Zejc, A. Search for new anticonvulsant compounds. Part 1 : Synthesis, physicochemical and anticonvulsant properties of new derivatives of $\alpha$-amino- $\gamma$-phthalimidobutyric acid. Pharmazie 1995, 50, 722-755.

[77] Mendyk, A.; Sa Xat, K.; Librowski, T.; Czarnecki, T.; Malawska, B. Influence of new $\gamma$-aminobutyric acid amide derivatives and its phthalimide precursors on the central nervous system activity in mice. Pol. J. Pharmacol. 2001, 53, 689-693.

[78] Malawska, B.; Kulig, K.; Ciechanowicz-Rutkowska, M. Search for new anticonvulsant compounds, Part 2: Structure-activity relationship studies of new $N$-substituted amides of $\alpha$-piperazine- $\gamma$ hydroxybutyric acid as active anticonvulsants. Arch. Pharm. Pharm. Med. Chem. 1997, 330, 91-99.

[79] Malawska, B.; Antkiewicz-Michaluk, L. Search for new anticonvulsant compounds, Part 3. Synthesis, physicochemical properties, anticonvulsant activities and voltage-sensitive calcium channels affinity of $N$-substituted amides of $\alpha$-(4phenylpiperazine)-GABA. Pharmazie 1999, 54, 239-243.

[80] Malawska, B.; Kulig, K.; Antkiewicz-Michaluk, L.; Cliffe, I.; Porter, R.; Misra, A. Anticonvulsant activities and voltage-sensitive calcium channels receptor affinity of substituted $N$-benzylamides of $\gamma$-amino- and $\gamma$-hydroxybutyric acid. Arch. Pharm. Pharm. Med. Chem. 1999, 332, 167-174.

[81] Sałat, K.; Mendyk, A.; Librowski, T.; Czarnecki, R.;Malawska, B. Influence of new $\gamma$-hydroxybutyric acid amide analogues on the central nervous system activity in mice. Pol. J. Pharmacol. 2002, 54, 731-736.

[82] Malawska B.; Kulig K.; Bendieck E. Comparison of chromatographically determined values of the lipophilicity of anticonvulsant active $N$-substituted amides of $\alpha$-arylalkylamine- $\gamma$ hydroxybutyric acid with values estimated by computational methods. J. Planar Chromatogr. 2003, 16, 390-395.

[83] Malawska, B. Searching of $\gamma$-amino- and $\gamma$-hydroxybutyric acid analogues with expected anticonvulsant activity (Polish). Wiad. Chem. 2001, 55, 377-402.

[84] Malawska, B.; Kulig, K. Śpiewak, A.; Stables, J.P. Investigation into new anticonvulsant derivatives of $\alpha$-subsituted $N$-benzylamides 
of $\gamma$-hydroxy- and $\gamma$-acetoxybutyric acid. Part. 5: Search for new anticonvulsant compounds. Bioorg. Med. Chem. 2004, 12, 625-632.

[85] Hinko, C.N.; Crider, A.M.; Kliem, M.A.; Steinmiller, C.I.; Seo, T.H.; Ho, B.; Venkatarangan, P.; El-Assadi, A.A.; Chang, H.; Burns, C.M.; Tietz, E.I.; Andersen, P.H.; Klitgaard, H. Anticonvulsant activity of novel derivatives of 2- and 3piperidinecarboxylic acid in mice and rats. Neuropharmacology 1996, 35, 1721-1735.

[86] Ho, B.; Venkatarangan, P.; Cruse, S.F.; Hinko, C.N.; Andersen, P.H.; Crider, A.M.; Adloo, A.A.; Roane, D.S.; Stables, J.P. Synthesis of 2-piperidinecarboxylic acid derivatives as potential anticonvulsants. Eur. J. Med. Chem. 1998, 33, 23-31.

[87] Ho, B.; Crider, A.M.; Stables, J.P. Synthesis and structure-activity relationships of potential anticonvulsants based on 2piperidinecarboxylic acid and related pharmacophores. Eur. J. Med. Chem. 2001, 36, 265-286

[88] Brown, M.L.Z.C.C.; Van Dyke, C.C.; Brown, G.B.; Brouillette, W.J. Comparative molecular field analysis of hydantoin binding to the neuronal voltage-dependent sodium channel. J. Med. Chem. 1999, 42, 1537-1545.

[89] Schenck, H.A.; Lenkowski, P.W.; Choudhury-Mukherjee, I.; Ko, S.-H.; Stables, J.P.; Patel, M.K.; Brown, M.L. Design, synthesis and evaluation of novel hydroxyamides as orally available anticonvulsants. Bioorg. Med. Chem. 2004, 12, 979-993.

[90] Marona, H.; Szneler, E. Preliminary evaluation of anticonvulsant activity of some 4-(benzyloxy)-benzamides. Acta Pol. Pharm. Drug-Res. 2003, 60, 477-480.

[91] Karakurt, A.; Dalkara, S.; Özalp, M.; Özbey, S.; Kendi, E.; Stables, J.P. Synthesis of some 1-(2-naphthyl)-2-(imidazole-1-yl)ethanone oxime and oxime ether derivatives and their anticonvulsant and antimicrobial activities. Eur. J. Med. Chem. 2001, 36, 421-433.

[92] Zejc, A.; Obniska, J.; Wilimowski, M.; Rutkowska, M.; Witkowski, J.; Barczyńska, L.; Kędzierska-Goździk, L.; Wojewódzki, W.; Orzechowska-Juzwenko, K.; Plawiak, T.; Duś, E.; Gryska, J.; Gliniak, M. Synthesis and anticonvulsant properties of some arylsuccinate methylpyridylimides. Pol. J. Pharmacol. Pharm. 1990, 42, 69-77.

[93] Obniska, J.; Kulig, K.; Zejc, A. Synthesis and anticonvulsant properties of new $N$-piperazinylalkyl imides of succinic acid. Acta Pol. Pharm.-Drug Res. 1998, 55, 223-231.

[94] Obniska, J.; Zejc, A.; Karolak-Wojciechowska, J. Synthesis and anticonvulsant properties of new $\mathrm{N}$-pyridyl derivatives of 3-phenyland 3,3-diphenyl-succinimides. Farmaco 1999, 54, 423-429.

[95] Obniska, J.; Zejc, A.; Zagórska, A. Synthesis and anticonvulsant properties of new 1-phenyl and 1-phenylamino-3-phenylpyrrolidine-2,5-dione derivatives Acta Pol. Pharm.-Drug Res. 2002, 59, 209-213.

[96] Obniska, J.; Zagórska, A. Synthesis and anticonvulsant properties of new $\mathrm{N}$-[(4-arylpiperazin-1-yl)-methyl] derivatives of 3-aryl pyrrolidine-2,5-dione and 2-aza-spiro[4.4]nonane-1,3-dione. Farmaco 2003, 58, 1227-1234.

[97] Brouillette, W.J.; Grunewald, G.L. Synthesis and anticonvulsant activity of some substituted lactams and amides. J. Med. Chem. 1984, 27, 202-206.

[98] Reddy, P.A.; Hsiang, B.C.H.; Latifi, T.N.; Hill, M.W.; Woodward, K.E.; Rothman, S.M.; Ferrendelli, J.A.; Covey, D.F. 3.3-Dialkyland 3-alkyl-3-benzyl-substituted 2-pyrrolidinones: A new class of anticonvulsant agents. J. Med. Chem. 1996, 39, 1898-1906.

[99] Reddy, P.A.; Woodward, K.E.; McIlheran, S.M.; Hsiang, B.C.H.; Latifi, T.N.; Hill, M.W.; Rothman, S.M.; Ferrendelli, J.A.; Covey, D.F. Synthesis and anticonvulsant activities of 3,3-dialkyl- and 3alkyl-3-benzyl-2-piperidinones ( $\delta$-valerolactams) and hexahydro2H-azepin-2-ones (E-caprolactams). J. Med. Chem. 1997, 40, 44-49.

[100] Grimm, J.B.; Stables, J.P.; Brown, M.L. Design, synthesis, and development of novel caprolactam anticonvulsants. Bioorg. Med. Chem. 2003, 11, 4133-4141.

[101] Dimmock, J.R.; Sidhu, K.K.; Tumber, S.D.; Basran, S.K.; Chen, M.; Quail, J.W.; Yang, J.; Rozas, I.; Weaver, D.F. Some aryl semicarbazones possessing anticonvulsant activities. Eur. J. Med. Chem. 1995, 30, 287-301.

[102] Dimmock, J.R.; Pandeya, S.N.; Quail, J.W.; Pugazhenthi, U.; Allen, T.M.; Kao, G.Y.; Balzarini, J.; DeClercq, E. Evaluation of the semicarbazones, thiosemicarbazones and bis-carbohydrazones of some aryl alicyclic ketones for anticonvulsant and other biological properties. Eur. J. Med. Chem. 1995, 30, 303-314.
[103] Dimmock, J.R.; Puthucode, R.N.; Smith, J.M.; Hetherington, M.; Quail, J.W.; Pugazhenthi, U.; Lecher, T.; Stables, J.P. (Aryloxy)aryl semicarbazones and related compounds: a novel class of anticonvulsant agents possessing high activity in the maximal electroshock screen. J. Med. Chem. 1996, 39, 3984-3997.

[104] Puthucode, R.; Pugazhenthi, U.; Quail, J.W.; Stables, J.P.; Dimmock, J.R. Eur. J. Med. Chem. 1998, 33, 595-607.

[105] Pandeya, S.N.; Ponnilavarasan, I.; Pandey, A. ; Lakhan, R. ; Stables, J.P. Evaluation of p-nitrophenyl substituted semicarbazones for anticonvulsant properties. Pharmazie 1999, 54, 923-925.

[106] Dimmock, J.R.; Vashishtha, S.C.; Stables, J.P. Anticonvulsant properties of various acetylhydrazones, oxamoylhydrazones and semicarbazones derived from aromatic and unsaturated carbonyl compounds. Eur. J. Med. Chem. 2000, 35, 241-248.

[107] Pandeya, S.N.; Yogeeswari, P.; Stables, J.P. Synthesis and anticonvulsant activity of 4-bromophenyl substituted aryl semicarbazones. Eur. J. Med. Chem. 2000, 35, 879-886.

[108] Pandeya, S.N.; Mishra, V.; Ponnilavarasan, I.; Stables, J.P. Anticonvulsant activity of $p$-chlorophenyl substituted aryl semicarbazones - The role of primary terminal amino group. Pol. J. Pharmacol. 2000, 52, 283-290.

[109] Dimmock, J.R.; Vashishtha, S.C.; Stables, J.P. Ureylene anticonvulsants and related compounds. Pharmazie 2000, 55, 490494.

[110] Pandeya, S.N.; Manjula, H.; Stables, J.P. Design of semicarbazones and their bio-isosteric analogues as potential anticonvulsants. Pharmazie 2001, 56, 121-124.

[111] Yogeeswari, P.; Sriram, D.; Sunil Jit, L.R.; Kumar, S.S.; Stables J.P. Anticonvulsant and neurotoxicity evaluation of some 6chlorobenzothiazolyl-2-thiosemicarbazones. Eur. J. Med. Chem. 2002, 37, 231-236.

[112] Pandeya, S.N.; Agarwal, A.K.; Singh, A.; Stables, J.P. Design and synthesis of semicarbazones and their bio-isosteric analogues as potent anticonvulsants: The role of hydrogen bonging. Acta Pharm. 2003, 53, 15-24.

[113] Popp, F.D. Potential anticonvulsants. IX. Some isatin hydrazones and related compounds. J. Heteroc. Chem. 1984, 21, 1641-1645.

[114] Pandeya, S.N.; Sriram, D.; Yogeeswari, P.; Stables, J.P. Anticonvulsant and neurotoxicity evaluation of 5-(un)-substituted isatin-imino derivatives. Pharmazie 2001, 56, 875-876.

[115] Srivastava, A.V.K.; Kumar, A. Synthesis of newer thiadiazolyl and thiazolidinonyl quinazolin-4(3H)-ones as potential anticonvulsant agents. Eur. J. Med. Chem. 2002, 37, 873-882.

[116] Chapleo, C.B.; Mayer M.; Myer, P.L.; Saville, J.F.; Smith, A.C.B.; Stilling, M.R.; Tulloch, I.F.; Walter, D.S.; Welbourn, A.P.; Substituted 1,3,4-thiadiazoles with anticonvulsant activity. 1 . Hydrazines J. Med. Chem. 1986, 29, 2273-2280.

[117] Srivastava, A.V.K. ; Kumar, A. ; Synthesis of some newer derivatives of substituted quinazolinonyl-2-oxo/thiobarbituric acid as potent anticonvulsant agents. Bioorg. Med. Chem. 2004, 12, 1257-1264.

[118] Dogan, H.N.; Duran, A.; Rollas, S.; Sener, G.; Uysal. M.K.; Gülen, D. Synthesis of new 2,5-disubstituted-1,3,4-thiadiazoles and preliminary evaluation of anticonvulsant and antimicrobial activities. Bioorg. Med. Chem. 2002, 10, 2893-2898.

[119] Marona, H.; Górka, Z.; Szneler, E. Aminoalkanolic derivatives of xanthone with potential antiepileptic activity. Pharmazie 1998, 53, 219-223.

[120] Marona, H. Evaluation of some 2-substituted derivatives of xanthone for anticonvulsant properties. Pharmazie 1998, 53, 405409.

[121] Marona, H. Synthesis and anticonvulsant effects of some aminoalkanolic derivatives of xanthone. Pharmazie 1998, 53, 672676.

[122] Marona, H.; Pękala, E.; Filipek, B.; Macięg, D.; Szneler, E. Pharmacological properties of some aminoalkanolic derivatives of xanthone. Pharmazie 2001, 56, 567-572.

[123] Jastrzębska-Więsek, M.; Librowski, T.; Czarnecki, T.; Marona, H.; Nowak, G. Central activity of new xanthone derivatives with chiral center in some pharmacological tests in mice. Pol. J. Pharmacol. 2003, 55, 461-465.

[124] Sridhar, S.K.; Pandeya, S.; Stables, J.P.; Ramesh, A. Anticonvulsant activity of hydrazones, Schiff and Mannich bases of isatin derivatives. Eur. J. Pharm. Sc. 2002, 16, 129-132. 
[125] Sridhar, S.K.; Ramesh, A. Synthesis and pharmacological activities of hydrazones, Schiff and Mannich bases of isatin derivatives. Biol. Pharm. Bull. 2001b, 24, 1149-1152.

[126] Verma, M.; Pandeya, S.N.; Singh, K.N.; Stables, J.P. Anticonvulsant activity of Schiff bases of isatin derivatives. Acta Pharm. 2004, 54, 49-56.

[127] Alexander, M.S.; Stables, J.P.; Ciechanowicz-Rutkowska, M.; Hursthouse, M.B.; Hibbs, D.E.; Edafiogho, I.O.; Moore, V.A.; Scott, K.R. Spiranes 6. Ring A homologues of N-benzyloxy-2azaspiro[4,4]nonane-1,3-dione. Synthesis, X-ray analysis and anticonvulsant evaluation. Eur. J. Med. Chem. 1996, 31, 787-795.

[128] Foster, J.E.; Nicholson, J.M.; Butcher, R.; Stables, J.P.; Edafiogho, I.O.; Goodwin, A.M.; Henson, M.C.; Smith, C.A.; Scott, K.R. Synthesis, characterization and anticonvulsant activity of enaminones. Part 6: Synthesis of substituted vinylic benzamides as potential anticonvulsants. Bioorg. Med. Chem. 1999, 7, 2415-2425.

[129] Eddington, N,D,; Cox, D.S.; Roberts, R.R.; Stables, J.P.; Powell, C.B.; Scott, K.R. Enaminones-versatile therapeutic pharmacophores. Further advances. Curr. Med. Chem. 2000, 7, 417-436.

[130] Cox, D.S.; Scott, K.R.; Gao, H.; Eddington, N.D. Influence of multidrug resistance (MDR) proteins at the blood-brain barrier on the transport and brain distribution of enaminone anticonvulsants. $J$. Pharm. Sci. 2001, 90, 1540-1552.

[131] Eddington, N.D.; Cox, D.S.; Roberts, R.R.; Butcher, R.J.; Edafiogho, I.O.; Stables, J.P.; Cooke, N.; Goodwin, A.M.; Smith, C.A.; Scott, K.R. Synthesis and anticonvulsant activity of enaminones. 4. Investigation on isoxazole derivatives. Eur. J. Med. Chem. 2002, 37, 635-648.

[132] Edafiogho, I.O.; Phillips, O.A.; Abdel-Hamid, M.; Ali, A.A.M.; Matowe, W.C.; El-Hashim, A.; Kombian, S.B. Ultraviolet spectroscopy of anticonvulsant enaminones. Bioorg. Med. Chem. 2002, 10, 593-597.

[133] Cox, D.S.; Scott, K.R.; Gao, H.; Eddington, N.D. Effect of PGlycoprotein on the pharmacokinetics and tissue distribution of enaminone anticonvulsants: analysis by population and physiological approaches J. Pharmacol. Exp. Ther. 2002, 302, 1096-1104.

[134] Eddington, N.D.; Cox, D.S.; Khurana, M.; Salama, N.N.; Stables, J.P.; Harrison, S.J.; Negussie, A.; Taylar, R.S.; Tran, U.Q.; Moore, J.A.; Barrow, J.C.; Scott, K.R. Synthesis and anticonvulsant activity of enaminones Part 7. Synthesis and anticonvulsant evaluation of ethyl 4-[(substituted phenyl)amino]-6-methyl-2-oxocyclohex-3ene-1-carboxylates and their corresponding 5-methylcyclohex-2enone derivatives. Eur. J. Med. Chem. 2003, 38, 49-64. 